\title{
Review \\ Therapeutic Approaches Targeting Proteins in Tumor-Associated Macrophages and Their Applications in Cancers
}

\author{
Deyang $\mathrm{Wu}^{1}{ }^{1}$, Xiaowei Liu ${ }^{2}$, Jingtian Mu ${ }^{1}$, Jin Yang ${ }^{1}$, Fanglong $\mathrm{Wu}{ }^{1, *(\mathbb{D})}$ and Hongmei Zhou ${ }^{1, *}$ \\ 1 State Key Laboratory of Oral Diseases, National Center of Stomatology, National Clinical Research Center for \\ Oral Diseases, Frontier Innovation Center for Dental Medicine Plus, Department of Oral Medicine, West \\ China Hospital of Stomatology, Sichuan University, Chengdu 610041, China; scu_wudeyang@163.com (D.W.); \\ jingtianmou@163.com (J.M.); yangjin@scu.edu.cn (J.Y.) \\ 2 State Key Laboratory of Oral Diseases, West China College of Stomatology, Sichuan University, \\ Chengdu 610041, China; 2019151640145@stu.scu.edu.cn \\ * Correspondence: wufanglong@scu.edu.cn (F.W.); zhouhm@scu.edu.cn (H.Z.)
}

Citation: $\mathrm{Wu}, \mathrm{D} . ; \mathrm{Liu}, \mathrm{X} . ; \mathrm{Mu}, \mathrm{J} . ;$

Yang, J.; Wu, F.; Zhou, H. Therapeutic Approaches Targeting Proteins in Tumor-Associated Macrophages and Their Applications in Cancers. Biomolecules 2022, 12, 392.

https://doi.org/10.3390/ biom12030392

Academic Editors: Caterina

Vicidomini, Giovanni N. Roviello and Cédric Rébé

Received: 5 December 2021 Accepted: 28 February 2022 Published: 2 March 2022

Publisher's Note: MDPI stays neutral with regard to jurisdictional claims in published maps and institutional affiliations.

Copyright: (C) 2022 by the authors. Licensee MDPI, Basel, Switzerland. This article is an open access article distributed under the terms and conditions of the Creative Commons Attribution (CC BY) license (https:// creativecommons.org/licenses/by/ $4.0 /)$.

\begin{abstract}
Tumor-associated macrophages (TAMs) promote tumor proliferation, invasion, angiogenesis, stemness, therapeutic resistance, and immune tolerance in a protein-dependent manner. Therefore, the traditional target paradigms are often insufficient to exterminate tumor cells. These pro-tumoral functions are mediated by the subsets of macrophages that exhibit canonical protein markers, while simultaneously having unique transcriptional features, which makes the proteins expressed on TAMs promising targets during anti-tumor therapy. Herein, TAM-associated proteindependent target strategies were developed with the aim of either reducing the numbers of TAMs or inhibiting the pro-tumoral functions of TAMs. Furthermore, the recent advances in TAMs associated with tumor metabolism and immunity were extensively exploited to repolarize these TAMs to become anti-tumor elements and reverse the immunosuppressive tumor microenvironment. In this review, we systematically summarize these current studies to fully illustrate the TAM-associated protein targets and their inhibitors, and we highlight the potential clinical applications of targeting the crosstalk among TAMs, tumor cells, and immune cells in anti-tumor therapy.
\end{abstract}

Keywords: tumor-associated macrophages; tumor microenvironment; targeted therapy; protein

\section{Introduction}

Tumor-associated macrophages (TAMs), as an integral cellular component in the tumor microenvironment (TME), promote the process involved in tumor progression, including proliferation, infiltration, angiogenesis, metastasis, stemness, immune escape, and therapeutic resistance [1]. Previous studies have shown that TAMs can attenuate therapeutic effects by expressing various pro-tumor cytokines and chemokines, etc., decreasing T-cell infiltration, suppressing the function of immune cells, and fueling tumor cells, respectively [1-3]. Blocking the positive effects of TAMs on tumors and/or reducing the number of TAMs in the TME could suppress the tumor-promoting biological behaviors involved in carcinogenesis, progression, invasion, recurrence, and metastasis. For instance, TAMs would be beneficial for tissue remodeling and the construction of the tumor's physical barrier, which inhibit the infiltration of immune cells, such as $\mathrm{CD}^{+} \mathrm{T}$ cells [4].

Since the receptors in TAMs are less likely to undergo mutation, targeting their receptors would be a promising therapeutic approach for anti-tumor therapy. To support this notion, recently, in preclinical models, several special antibodies targeting their receptors were used against TAMs, including ch14.18, duvelisib (IPI-145), and ipilimumab, which were developed in neuroblastoma, T-cell lymphoma, and melanoma, respectively [5-7]. However, TAMs are highly plastic stromal cells [8], indicating that any therapeutic strategies 
developed to exploit the targeting proteins in TAMs should account for their heterogeneous nature in order to optimize treatment efficacy.

Infiltrated and polarized TAMs promote tumor progression in a direct manner through secreting multiple cytokines and/or chemokines, and an indirect manner, through recruiting the surrounding immune cells or remodeling the extracellular matrix (ECM). For instance, in a mouse model, Shono et al. provided evidence showing that Celecoxib inhibited the expression of the $\mathrm{C}-\mathrm{C}$ motif chemokine ligand 2 (CCL2) and $\mathrm{C}-\mathrm{X}-\mathrm{C}$ motif chemokine receptor 3 (CXCR3) to reduce the recruitment of TAMs [9]. In another study, Chow et al. showed that T-cell immunoglobulin and mucin domain-containing protein 4 $\left(\mathrm{Tim} 4^{+}\right)$macrophages (Tim4, a receptor for phosphatidylserine) combined directly with $\mathrm{CD}^{+} \mathrm{T}$ cells to attenuate the anti-tumor immune response [10]. Although these findings are promising, the many obstacles of targeting proteins in TAMs need to be further explored. For instance, the avenue for reducing the earliest recruitment of TAMs might not affect those TAMs that have finished recruitment. Additionally, drug delivery methods for targeting proteins in TAMs are constrained by vascular permeability, the ECM, and the tissue osmotic pressure, for instance, which decrease drug affinity. Indeed, compared with micromolecules, such as calcium ions, proteins, as the executors in many biochemical procedures, are easy to collect and analyze when targeted by drugs. Notably, the threedimensional structures, intracellular locations, and phosphorylation states of proteins in TAMs can affect the targeting efficacy. Thus, in this review, we systematically summarize the therapeutic approaches for targeting proteins in TAMs with regard to recruitment, polarization, crosstalk with tumor cells, and immune responses, highlighting potential strategies for targeting proteins in TAMs for anti-cancer treatment.

\section{Targeting Proteins in the Recruitment and Polarization of TAMs}

To date, overwhelming evidence suggests that the main cellular source of TAMs is recruitment and polarization [11,12]. Typically, monocytes or myeloid cells infiltrate from the blood circulation and/or local tissue, and then differentiate into macrophages. Induced by chemokines, cytokines and vascular endothelial growth factor (VEGF), for instance, in the TME, TAMs polarize toward the M1 phenotype (with pro-inflammatory and anti-tumor effects) and M2 phenotype (with anti-inflammatory and pro-tumor functions) to affect tumor progression $[13,14]$. On the other hand, TAMs can also be directly recruited from the surrounding tissue. Thus, to block TAMs' pro-tumor efficacy, decreasing their recruitment and attenuating their polarization have been extensively studied (Figure 1).

\subsection{TAM Recruitment and Its Targeted Therapy Based on Proteins}

TAM recruitment is mainly mediated by tumor cells and surrounding stromal cells through the release of diverse chemokines, including CCL5 and CCL2, and stromal glycoproteins can promote tumor progression by facilitating TAM recruitment from the circulation and/or local tissue to the tumor site (Table 1). For instance, Nie et al. showed that CCL5 derived from breast phyllode tumors was involved in TAM recruitment by binding with CCR5 on the membranes of TAMs, and the CCL5 inhibitor, maraviroc, was shown to attenuate TAM recruitment and suppress malignant progression [15], indicating that targeting CCR5 in TAMs might represent a potential strategy for decreasing recruitment in malignant breast phyllode tumors. Furthermore, several studies have shown that the expression of CCL2, followed by TAM recruitment, is positively correlated with the activation of NF- $\mathrm{KB}[16,17]$, suggesting that targeting the NF- $\mathrm{KB} / \mathrm{CCL} 2$ signal might be beneficial for blocking TAM recruitment. In agreement with this, in a mouse model, Shono et al. used celecoxib to suppress NF- $\mathrm{KB}$ and found that the downregulation of CCL2 attenuated TAM recruitment and increased the apoptosis of tumor cells in malignant glioma [9]. Collectively, these findings demonstrate that CCL2 might be a key regulator in chemokine-induced TAM recruitment and might exhibit great potential to be targeted in decreasing TAM recruitment. 


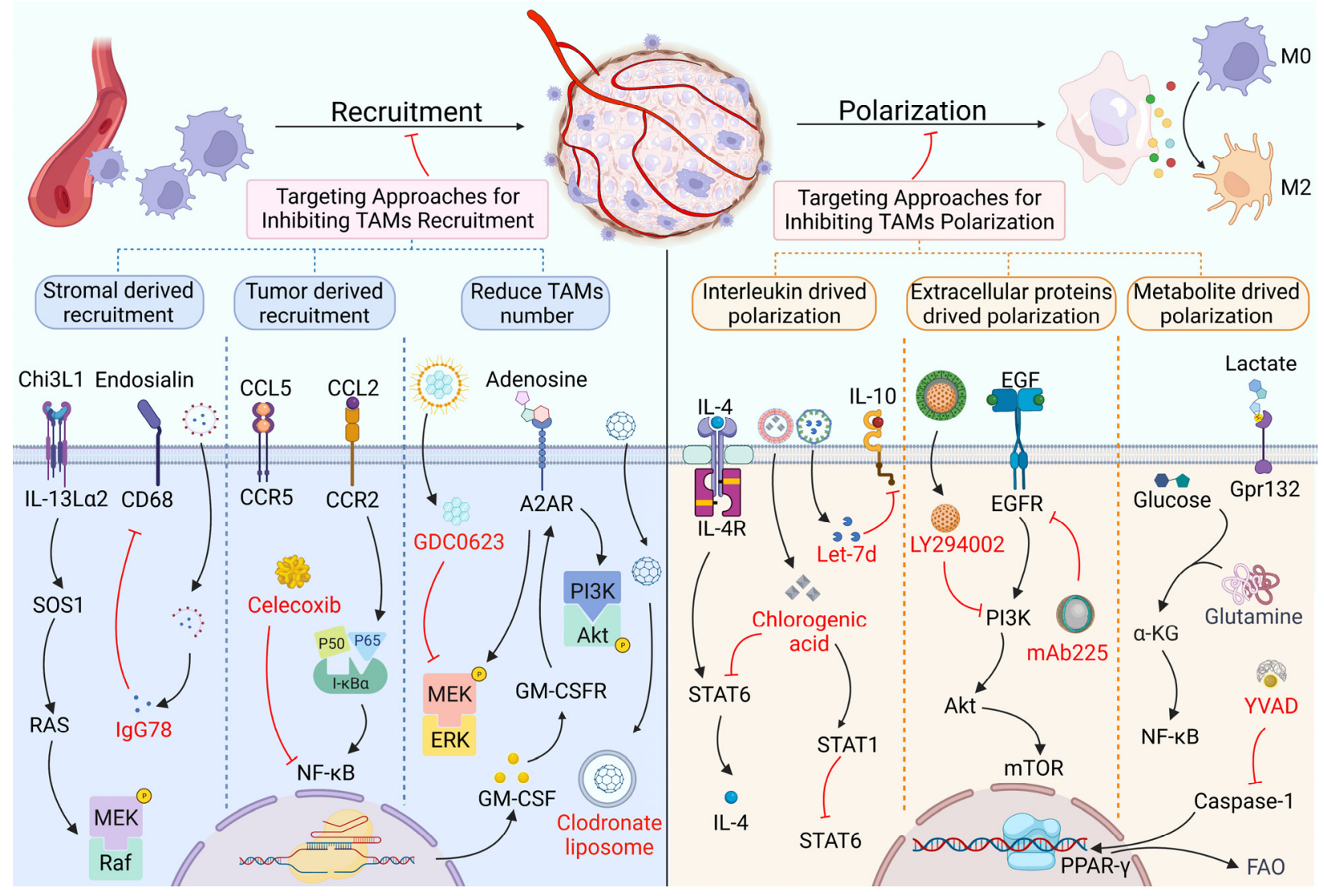

Figure 1. Targeting approaches for inhibiting TAM recruitment and polarization. TAMs are mainly recruited by the factors derived from stromal and tumor cells. These factors, including endosialin, chitinase 3-like protein (Chi3L1), C-C motif chemokine ligand 2 (CCL2), etc., could bind with their receptors in TAMs, then activating the downstream effectors to regulate the recruitment of TAMs through nuclear factor kappa-light-chain-enhancer of activated B cells (NF- $\kappa$ B), phosphoinositide 3-kinase/protein kinase B (PI3K/Akt), mitogen-activated protein kinase (MAPK), etc. signaling pathways. Targeting inhibitors, including IgG78, celecoxib and GDC0623 block CD68, the NF- $\mathrm{KB}$ and MEK signaling pathways inhibit TAM recruitment or reduce the number of TAMs. The polarization of TAMs is mediated by interleukins, extracellular proteins and metabolite. Tumor-derived Interleukin 4 (IL-4), IL-10, lactate and endothelial growth factor (EGF) could combine with IL4 receptor, IL-10 receptor, G-protein-coupled receptor 132 (Gpr132), and EGFR on TAMs to induce the polarization of TAMs via downstream signals, including PI3K/Akt/mTOR and signal transducers and activators of transcription 6 (STAT6) cascade. The chlorogenic acid, Let-7d, LY294002, mAb225 and YVAD could inhibit STAT6, IL-10 receptor, PI3K, EGFR and caspase-1 to attenuate TAM polarization.

Table 1. Targeting proteins for inhibiting TAM recruitment and polarization.

\begin{tabular}{cccccc}
\hline Target & Inhibitor & Tumor & Study Design & Anti-Tumor Mechanism \\
\hline CCL2 & Celecoxib & GBM & C57BL/6 J mice + Eagle medium F-12 & Decrease pNF-kB expression & [9] \\
\hline 6-Shogaol & BC & $\begin{array}{c}\text { MDA-MB-231/A549/4T1 } \\
\text { cell line + Leibovitz's L-15, } \\
\text { F-12K, etc. medium }\end{array}$ & $\begin{array}{c}\text { Decrease CCL2 by inhibiting } \\
\text { STAT3 activation }\end{array}$ \\
\hline CCR2 & Losartan & BC & 4T1-Luc, etc. cell line + ICR, etc. mice & Inhibit CCL2-induced p-ERK1/2 & [19] \\
\hline CXCL1 & Aiduqing & BC & $\begin{array}{c}\text { 4T1/293 T cell line + BALB/c } \\
\text { mice + DMEM/RPMI-1640 }\end{array}$ & $\begin{array}{c}\text { Decrease Tregs differentiation } \\
\text { and infiltration }\end{array}$ \\
\hline CCR5 & Maraviroc & BC & MDA-MB-436/4T1.2 cell line + DMEM & Inhibit TAM recruitment & [21] \\
\hline
\end{tabular}


Table 1. Cont.

\begin{tabular}{|c|c|c|c|c|c|}
\hline Target & Inhibitor & Tumor & Study Design & Anti-Tumor Mechanism & Ref. \\
\hline CCL5 & HuR & $\mathrm{BC}$ & MCF-7/MDA-MB-231 cell line + DMEM & Inhibit CCL5 expression & [22] \\
\hline CCR1 & J113863 & FA & $\begin{array}{l}\text { NCTC } 2472 \text { cell line + NCTC } 135 \\
\text { medium + C57BL/6, C3H/He mice }\end{array}$ & Inhibit thermal hyperalgesia & [23] \\
\hline CXCR7 & CCX771 & $\mathrm{BC}$ & 4T1 cell line + DMEM + BALB /c mice & Reduce p-STAT3 activation & [24] \\
\hline \multirow[t]{2}{*}{ CXCL8 } & IFN- $\gamma$ & PC & BxPC-3, etc. cell line + C57BL $/ 6$ mice & Inhibit macrophages traffic & [25] \\
\hline & ACPP Antibody & NPC & C666-1 cell line + RPMI 1640 medium & Inhibit PI3K/AKT pathway & [26] \\
\hline IL-1 $\beta$ & Anakinra & $\mathrm{BC}$ & $4 \mathrm{~T} 1$ cell line $+\alpha-\mathrm{MEM}+\mathrm{BALB} / \mathrm{c}$ mice & Inhibit CCL5, CXCX12 expression & [27] \\
\hline IL-6 & Siltuximab & OC & $\begin{array}{l}\text { Tissue from ovarian cancer } \\
\text { patients + endotoxin- } \\
\text { free RPMI/DMEM medium }\end{array}$ & $\begin{array}{l}\text { Reduce cytokine and chemokine, } \\
\text { inhibit IL-6 signaling }\end{array}$ & [28] \\
\hline S100B & Duloxetine & GLA & $\begin{array}{c}\text { GL261-Luc/KR158B } \\
\text { cell line + DMEM }+C X_{3} C R_{1}{ }^{G F P} \text { mice }\end{array}$ & Decrease CCL2 expression & [29] \\
\hline CSF-1R & PLX3397 & HCC & $\begin{array}{c}\text { Hep3B/HepG2/THP-1, etc. } \\
\text { cell line + OPN knockout C57BL/6 mice }\end{array}$ & $\begin{array}{l}\text { Inhibit PPAR } \gamma \text { activity to reduce } \\
\text { TAM numbers }\end{array}$ & [30] \\
\hline $\mathrm{A} 2 \mathrm{~A}$ & SCH58261 & HCC & Tissue from HCC patients & $\begin{array}{l}\text { Reduce Akt and ERK } \\
\text { phosphorylation to reduce } \\
\text { TAM numbers }\end{array}$ & [31] \\
\hline MEK & GDC-0623 & PC & $\begin{array}{l}\text { PDA30364 cell line + pan monocyte } \\
\text { isolation kit }\end{array}$ & Exterminate M2 macrophages & [32] \\
\hline \multicolumn{6}{|c|}{ Inhibit the polarization of TAMs } \\
\hline STAT6 & Gefitinib & LLC & $\begin{array}{l}\text { Cells from Chinese Academy of } \\
\text { Sciences + DMEM + C57BL } / 6 \text { mice }\end{array}$ & Inhibit IL-13/STAT6 pathway & [33] \\
\hline CSF-1R & BLZ945 & GLA & $\begin{array}{c}\text { U-87 MG, etc. } \\
\text { cell line + RCAS-hPDGF-B/Nestin-Tv-a; } \\
\text { Ink4a/Arf }{ }^{-/-} \text {mice }\end{array}$ & Inhibit heterotypic signaling & [34] \\
\hline YAP & Ovatodiolide & CRC & $\begin{array}{c}\text { HT-29, etc. cell line + Serum-Free } \\
\text { Medium + NOD, SCID, BALB/c mice }\end{array}$ & Suppress IL-6 induced pathway & [35] \\
\hline IL-6R & СРEB3 & CRC & $\begin{array}{l}\text { SW480/HCT116/LoVo, } \\
\text { etc. cell line + BALB/c mice }\end{array}$ & $\begin{array}{l}\text { Inhibit epithelial-mesenchymal } \\
\text { transition }\end{array}$ & [36] \\
\hline Ang-2 & AS16 & SA & Plasmid pPIC3.5K + BMMY + SD rat & Inhibit M2 polarization & [37] \\
\hline Integrin $\beta 3$ & Sc-7312 & $\mathrm{BC}$ & $\begin{array}{l}\text { 4T1/HEK293T cell line + RPMI-1640 and } \\
\text { DMEM + BALB/c mice }\end{array}$ & $\begin{array}{l}\text { Inhibit integrin } \beta 3 \text { induced } \\
\text { PPAR } \gamma \text { activity }\end{array}$ & [38] \\
\hline EP4 & TP-16 & CRC & $\begin{array}{l}\text { CT26/4T1/HCT116 cell line + DMEM and } \\
\text { F12 medium + C57BL/6, etc. mice }\end{array}$ & $\begin{array}{l}\text { Reprogram IMCs, enhance } \\
\text { tumor elimination }\end{array}$ & [39] \\
\hline CD206 & RP-182 & PC & $\begin{array}{l}\text { CD206 }{ }^{\text {high }} \text { M2-like macrophages }+ \text { KPC, } \\
\text { KP16 mice }\end{array}$ & $\begin{array}{l}\text { Reduce M2-like TAMs, improve } \\
\text { antitumor immune responses }\end{array}$ & [40] \\
\hline PlGF & HRG & BT & $\begin{array}{l}\text { T241/Panc02 cell line }+ \text { C57BL } / 6, \\
\text { BALB } / \text { c mice }\end{array}$ & $\begin{array}{l}\text { Promote vessel normalization, } \\
\text { improve tumor perfusion }\end{array}$ & [41] \\
\hline
\end{tabular}

GLA: glioma; GBM: glioblastoma multiforme; HCC: hepatocellular carcinoma; PC: prostate cancer; CRC: colorectal cancer; PDAC: pancreatic ductal adenocarcinoma; BC: breast cancer; BT: breast tumor; BPT: breast phyllodes tumors; SC: squamous cancer; LC: lung cancer; LCC: Lewis lung cancer; SCLC: small cell lung cancer; NSCLC: non-small cell lung cancer; NPC: nasopharyngeal carcinoma tumor; FA: fibrosarcoma; SA: sarcoma; OC: ovarian cancer; CCL2: C-C motif chemokine 2; CXCL1: C-X-C motif chemokine 1; CXCR1: C-X-C motif chemokine 1; CCR2: C-C motif chemokine 2; IL-1 $\beta$ : interleukin $1 \beta$ : CSF-1R: colony-stimulating factor 1 receptor; YAP: Yes-associated protein; AMPK: AMP-activated protein kinase; Ang2: angiopoietin-2; MEK: MAPK/extracellular signal-regulated kinase; EP4: prostaglandin E2 (PGE2) receptor 4; HuR: human antigen R; CPEB3: Cytoplasmic polyadenylation element binding protein 3; AS16: 16-kilodalton protein: HRG: histidine-rich glycoprotein; STAT: signal transducer and activator of transcription.

In stromal cells, we found that the expression of IL-1 $\beta$ in periodontal inflammation tissue was positively correlated with the production of both CCL2 and CCL5 in BC, and performing anakinra, an IL-1 $\beta$ inhibitor, could reduce myeloid-derived suppressor cell (MDSC) recruitment [27]. Yang et al. found that endosialin expressed by cancer-associated fibroblasts (CAFs) can interact with the glycoproteins existing on the surfaces of TAM membranes, such as CD68 (the major biomarker in TAMs), inducing both the recruitment 
and polarization of TAMs, and this process could be inhibited by IgG78 in hepatocellular carcinoma (HCC) [42], suggesting that endosialin and CD68 might be targeted for TAMs recruitment. However, there are few studies on targeting CD68 in TAM recruitment and polarization. An alternative hypothesis is that CD68 is a kind of lysosomal/endosomalassociated membrane glycoprotein with a smaller fraction on the cell surface, and an anti-CD68 antibody can recognize the antigen, but not trigger the lysosomal/endosomal cascades for functional properties. Another kind of secreted glycoprotein, chitinase 3-like protein (Chi3L1), can also favor the recruitment of TAMs in cancers. To identify the stromalderived Chi3L1 in TAM infiltration, Cohen et al. found that CAFs-derived Chi3L1 could induce pro-inflammatory signaling in tumor cells, promoting the release of chemokines, such as CCL2, facilitating TAM recruitment and promoting tumor growth in BC [43]. In sum, the above evidence shows that glycoproteins, especially Chi3L1 in stromal cells, including CAFs and TAMs, have the potential to be commonly targeted for blocking TAM recruitment.

Another strategy for decreasing TAM recruitment is to reduce their number directly by the application of inhibitors, clodronate liposomes, among others. On the one hand, since the granulocyte-macrophage colony-stimulating factor (GM-CSF) can upregulate macrophages proliferation [44], Wang et al. showed that TAMs can autocrine GM-CSF and recognize adenosine by the upregulation of $\mathrm{A} 2 \mathrm{~A}$ receptors, subsequently activating PI3K/Akt and MEK/ERK cascades, increasing the proliferation of macrophages [31]. On the other hand, given that the activity of the p38 MAPK cascade of M1 macrophages induces these cells to be independent of the MEK/ERK pathway, Baumann et al. performed a MEK inhibitor (MEKi), GDC-0623, to block the MEK/ERK pathway and found that M2 macrophages were highly fragile to the MEKi, while the existence of the p38 MAPK cascade can protect M1 macrophages from death induced by MEKi [32]. In our preliminary study, we found that clodronate liposome could significantly reduce TAMs and splenic macrophages, resulting in reduced squamous cell carcinoma volumes [45]. Mechanistically, clodronate liposome can be engulfed by TAMs via phagocytosis, and accumulated clodronate can be released by lysosomal/endosomal systems; therefore, TAMs would be eliminated at a certain intracellular concentration of clodronate [46]. In summary, these studies demonstrate that suppressing TAM proliferation or promoting TAM ablation can effectively reduce the number of TAMs in the TME, attenuating tumor progression.

\subsection{TAM Polarization and Its Targeted Therapy Based on Proteins}

Given that proteins, such as interleukins, can promote the polarization of TAMs toward the M2 phenotype, targeting those interleukins might achieve good anti-tumor efficacy. For instance, Su et al. found that blocking IL-10 by Let-7d was able to inhibit M2 polarization in renal cell carcinoma [47], and Rahal et al. found that exogenous IL-4 and IL-13 induced the phosphorylation of signal transducers and activators of transcription 6 (STAT6) and increased M2 polarization in the radioresistance of BC [48]. Contrary to this, Fu et al. found that STAT6 increased myeloid cells' polarization to M2 by the upregulation of IL-4 in lung cancer [49]. Similarly, Xue et al. used chlorogenic acid (CHA) to promote STAT1 activation, while inhibiting the activation of STAT6, subsequently, suppressing the polarization of M2 macrophages, and, as a result, inhibiting the tumor growth of glioblastoma in vivo [50]. Indeed, TAM polarization has been demonstrated to be modulated by the STAT6 signal cascade [51]. In sum, this evidence suggests that the relationship between IL-4 and STAT6 might be bidirectional, and any targeted strategy based on targeting STAT6 and IL-4 to block TAM polarization should be aware of their interaction in order to optimize therapeutic efficacy.

Additionally, extracellular proteins, such as endothelial growth factor (EGF), can induce M2 polarization by the activation of the EGF/PI3K/Akt/mTOR signaling pathway, and the EGFR antibody mAb225 and PI3K inhibitor LY294002 have been shown to suppress M2 polarization from monocytes in colon cancer $[52,53]$. However, recently, few studies have shown the potential targets of PI3K in TAM polarization. One of the reasons for 
this is that the activation of the oncogenic PI3K pathway is achieved in diverse ways, and inhibitors, such as LY294002, have shown limited therapeutic efficacy in preclinical trials $[54,55]$. In addition to those extracellular factors, the proteins expressed on the surface of cell membranes, such as S100A9, have been reported to be involved in TAM polarization [56]. Mechanistically, Fusobacterium nucleatum, a type of Gram-negative oral commensal anaerobe, has been found to upregulate S100A9 in macrophages and then promote M2 polarization through the TLR4/NF-kB signaling cascade [56]. Similarly, Kwak et al. found that MDSC-derived macrophages could express the S100A9 protein persistently, and S100A9 also promoted M2 polarization in metastatic melanoma [57]. Although the S100A9 inhibitor paquinimod has been extensively studied in inflammation [58,59], it is unknown if S100A9 inhibitors, such as paquinimod, are effective in TAM polarization, as no such data exist for cancers to date.

Lactate has worked as a direct regulator in TAM polarization [60]. Chen et al. found that tumor-cell-derived lactate-induced M2 polarization of TAMs can be mediated by the G-protein-coupled receptor 132 (Gpr132) in mouse models of BC [61], while no special antibody-targeted Gpr132 protein has been developed for suppressing TAM polarization. Further, Colegio et al. demonstrated that tumor-derived lactic acid promotes M2-like protumoral macrophages through HIF-1 $\alpha$ stabilization [60]; conversely, Liu et al. and Tannahill et al. showed that glutamine-derived succinate promotes M1-like antitumoral macrophages through HIF- $1 \alpha$ stabilization [62,63]. Based on these last findings, the reduction in succinate levels and the increasing $\alpha$-ketoglutarate $(\alpha-K G) /$ succinate ratio by the blockade of the glutamine anaplerosis and gamma-aminobutyric acid (GABA) shunt pathway might inhibit TAM polarization in the antitumoral phenotype. Fatty acid oxidation (FAO) provides considerable energy for supporting macrophage polarization towards the M2 phenotype [64]. FAO is transcriptionally induced by peroxisome proliferation-activated receptor-gamma (PPAR $\gamma)[65,66]$. However, Niu et al. showed that PPAR $\gamma$ plays a negative role during the pro-tumorigenic polarization of TAMs in BC models, and the caspase-1 inhibitor YVAD, which inhibit the caspase-1 mediated cleavage of PPAR $\gamma$, attenuated the expression of markers specific for TAM polarization [65,67]. Furthermore, the activation of PPAR $\gamma$ is also attributed to a RIPK3 deficiency in TAMs. The lack of RIPK3 reduces ROS and significantly inhibits the caspase1-mediated cleavage of PPAR [68]. This indicates the paradoxical role of PPAR $\gamma$ in tumor progression, and such a discrepancy might be tissue specific or be controlled by unknown mechanisms in the downstream of the FAO metabolism. That M1 macrophages produce energy mainly through glycolysis, while M2 exhibits with a lower dependence on glycolysis and the TCA cycle occupies as the main source of ATP in M2 macrophages [69,70] indicates that glucose metabolism has a promising potential to be targeted for the conversion from M2 to M1 phenotype. To support it, Wei et al. performed the mannose-modified macrophage-derived microparticles (ManMPs) loading metformin (Met@Man-MPs, a kind of intervener in the glucose metabolism) to target the M2-like macrophages, subsequently converting TAMs from the M2 to M1 phenotype [71]. Taken together, targeting metabolic methods for the inhibition of TAM polarization or the conversion the TAMs from the M2 to M1 phenotype is a promising approach in anti-tumor therapy.

\section{Targeting Proteins in the Crosstalk between TAMs and Cancer Cells}

Generally, plenty of clinical and experimental studies have suggested that tumorigenesis is promoted in a macrophage-dependent manner [4,72,73]. TAMs, which abundantly surround most solid tumors, could facilitate tumor progression through stimulating tumor proliferation, invasion, angiogenesis, and stemness, or by providing a physical barrier that attenuates anti-tumor immune responses (Figure 2). TAM-mediated tumor progression has been found to be highly dependent on the activity of various pathways and the phosphorylation of diverse proteins (Table 2). Thus, to suppress tumor progression, a number of studies have extensively focused on protein-targeted therapies in inhibiting the crosstalk between TAMs and tumor cells. 

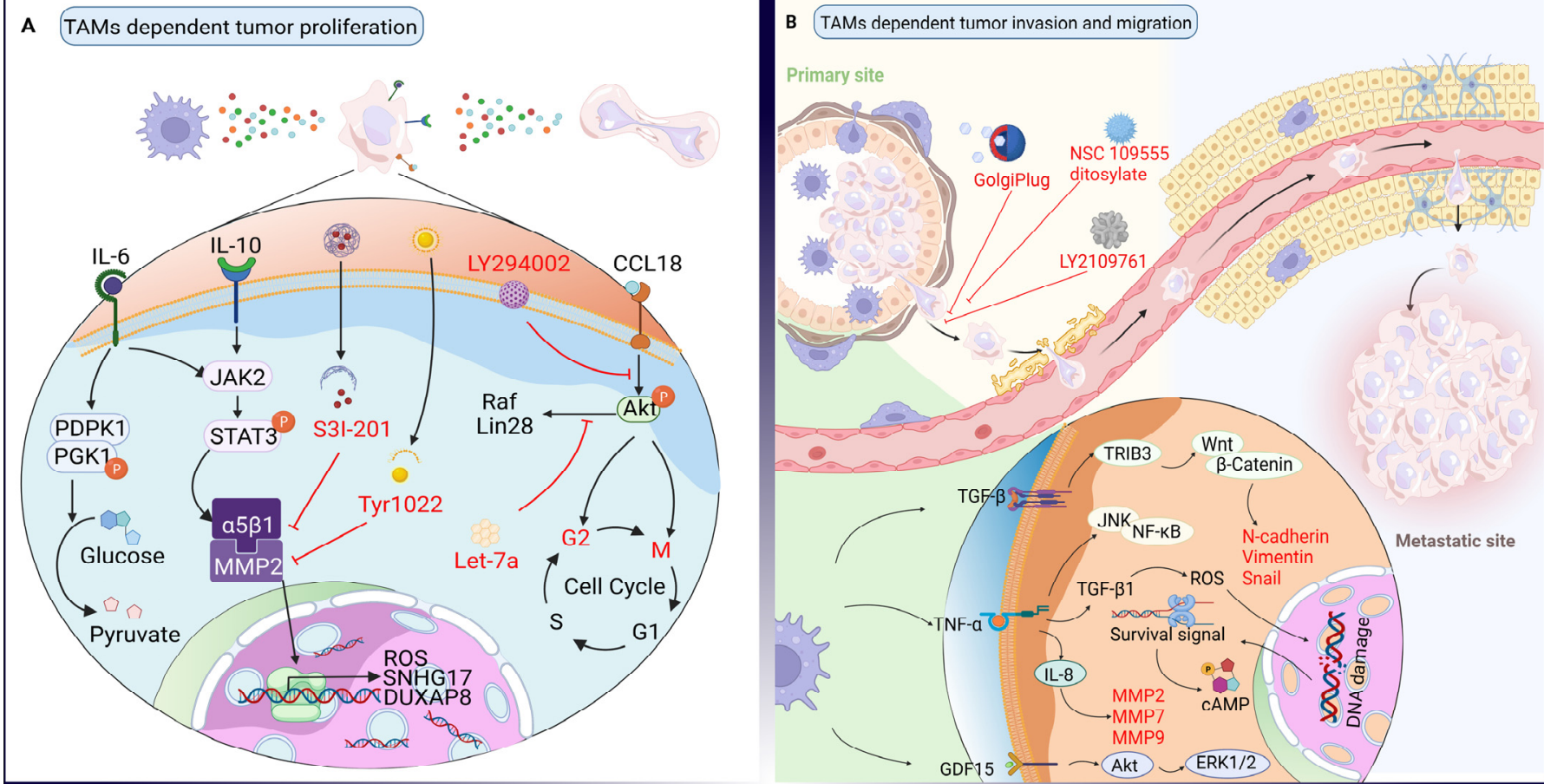

C TAMs dependent tumor angiogenesis

D TAMs dependent stemness and drug resistance
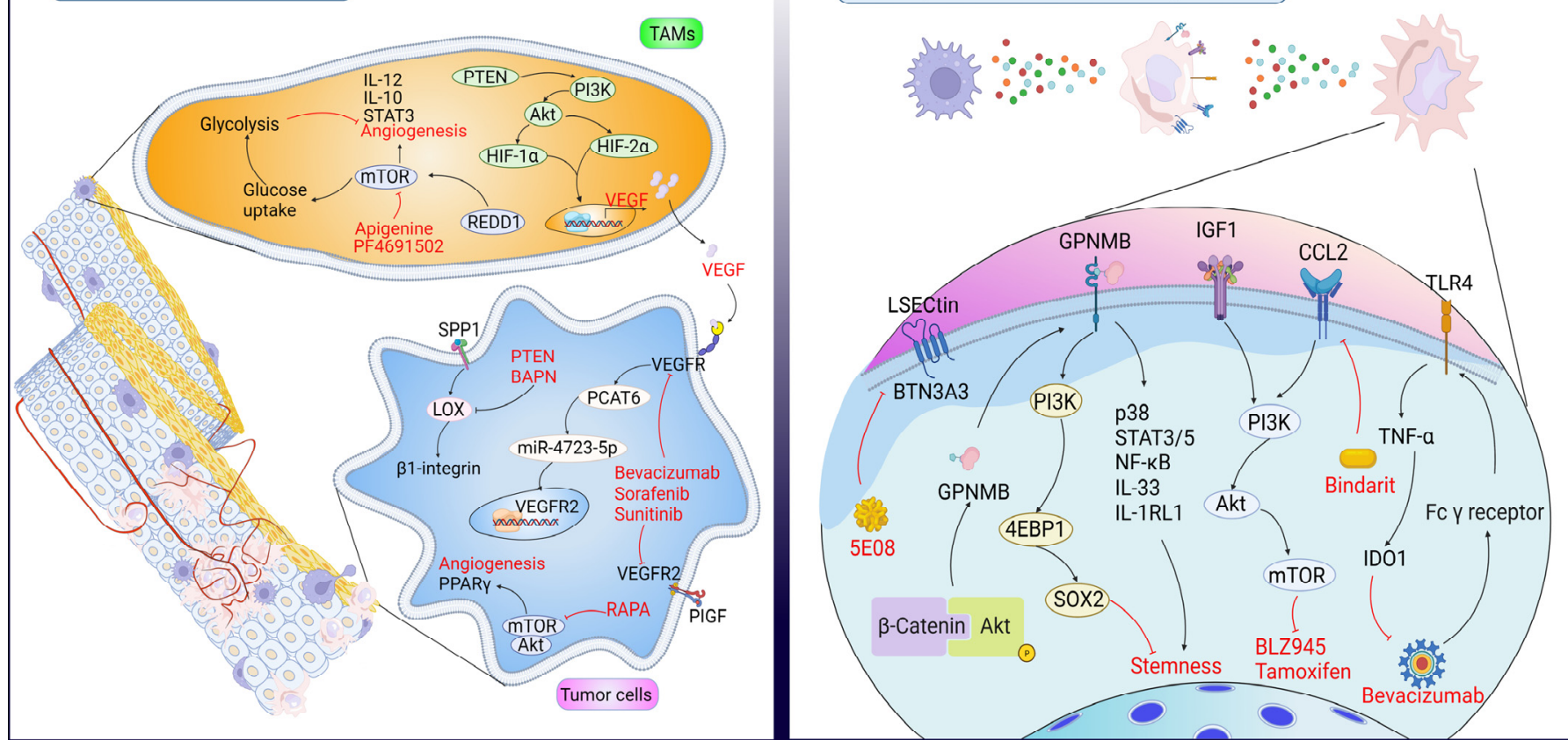

Figure 2. Targeting proteins in the crosstalk between TAMs and tumor cells. (A) In tumor cells, 3-phosphoinositide-dependent protein kinase 1 (PDPK1) is activated by TAMs derived IL-6, then phosphorylates phosphoglycerate kinase 1 (PGK1) to promote proliferation by pyruvate generation. TAM-derived IL-6 and IL-10 activate the JAK2/STAT3 cascade, then upregulate reactive oxygen species (ROS), SNHG17 and DUXAP8, to promote proliferation, while the S3I-201 and Tyr1022 could inhibit $\alpha 5 \beta 1$ integrin and MMP2, respectively, to inhibit this process. Similarly, TAM-derived CCL18 could activate the Akt signal, then prolong the $S$ phase and reduce the G1 phase of cell cycle, and promote the expression of Raf and Lin28. LY294002 and Let-7a could inhibit the activity of the Akt cascade. (B) Grow factors and cytokines, such as transforming growth factor-beta (TGF- $\beta$ ), combine with their reporters in tumor cells, then activate the downstream effector, including cAMP and ROS, to promote the invasion and metastasis of tumor cells. The application of inhibitors, such as LY2109761, 
could block the invasion and metastasis of tumor cells. (C) Angiogenesis is regulated by several major signals, such as the PTEN/PI3K/Akt and mammalian target of rapamycin (mTOR) signaling pathways, and the TAM-derived vascular endothelial growth factor (VEGF) is also involved in this process. Bevacizumab, sorafenib, and sunitinib can neutralize VEGFR and VEGFR2 in tumor cells. The PTEN and beta-aminopropionitrile (BAPN) in tumor cells inhibit lysyl oxidase (LOX) dependent $\beta 1$-integrin expression. Rapamycin (RAPA), Apigenine, and PF4691502 could block the mTOR signaling pathway to attenuate angiogenesis. (D) The cancer stemness would be mediated by LSECtin and the activity of $\beta$-Catenin/Akt pathway, while the $\beta$-Catenin/Akt pathway exhibits with a paradoxical role in the stemness of tumor cells. The IGF1 and CCL2 could bind with their receptors on tumor cells and then activate the PI3K/Akt/mTOR pathway to acquire the resistance of BLZ945 and Tamoxifen. Moreover, the metabolite of bevacizumab could interact with the Fc $\gamma$ receptor to induce the production of TNF- $\alpha$ and indoleamine 2,3-dioxygenase 1 (IDO1) by interacting with TLR4 to acquire the resistance of bevacizumab. The bindarit would inhibit CCL2 to attenuate the generation of drug resistance.

\subsection{Effects of TAMs on Cancer Cell Proliferation and Their Targeted Therapy Based on Proteins}

In addition to inducing TAM polarization, interleukin families, including IL-6 and IL-10, could promote cancer cell proliferation directly. For instance, in glioblastoma multiforme (GBM), Zhang et al. found that macrophage-derived IL-6 induced the phosphorylation of threonines (T243) in phosphoglycerate kinase 1 (PGK1), which was integral in GBM proliferation and the application of an anti-IL-6 antibody could abrogate this efficacy [74]. By Western blotting data, Mano et al. showed that TAM-derived IL-6 can promote HCC cell proliferation by inducing STAT3 phosphorylation and S3I-201 (a STAT3 inhibitor) could decrease IL-6-induced STAT3 phosphorylation for inhibiting HCC cell proliferation [75]. IL-6/STAT3 signaling has been found to be able to be mediated by integrin, a kind of membrane-spanning protein, and Kesanakurti et al. also provided findings illustrating that $\alpha 5 \beta 1$ integrin regulated IL-6/STAT3 signaling via interacting with matrix metallopeptidase 2 (MMP2) and Tyr1022, an $\alpha 5 \beta 1$ integrin inhibitor, can downregulate the activation of IL-6/STAT3 signaling and attenuate the proliferation of glioma [76], However, the targeting of the integrins of TAMs to inhibit tumor cell proliferation remains largely unexplored. Indeed, STAT3 can be activated by not only IL-6, but also IL-10. For instance, Yuan et al. reported that M2 macrophage secreted IL-10 could promote the proliferation of intrahepatic cholangiocarcinoma (ICC) cells through the STAT3 signaling pathway [77]. In sum, these studies suggest that TAM-associated tumor cell proliferation occurs in an IL-6 or IL-10/STAT3 signal cascade dependent manner and targeting proteins in the IL-6 or IL-10/STAT3 signaling pathway to attenuate tumor cell proliferation is promising in anti-tumor therapies.

Small-size secreted proteins, such as chemokines, are also involved in TAM-dependent tumor-cell proliferation. For instance, Wang et al. showed that M2 macrophage expressing CCL18 was associated with the activation of the FAK/PI3K/AKT pathway to promote the proliferation of esophageal squamous cell carcinoma (ESCC) cells, and that inhibiting PI3K by LY294002 to block the above pathway could impede the M2-induced proliferation of ESCC cells [78]. In another study, Wang et al. found that TAM-derived CCL18 could interfere with the cell cycle of BC cells by prolonging the $S$ phase and reducing the G1 phase [79]. In detail, they used Let-7a to attenuate TAM-derived CCL18 induced proliferation of BC cells by downregulating the Lin28 and Raf-protein expression to prolong the G2/M phase and reduce the S phase [79]. By contrast, in T-cell lymphoma (CTCL), Günther et al. found that CCL18, which is derived from CD209 ${ }^{+}$macrophages in mycosis fungoides (MF), the most frequent form of cutaneous T-cell lymphoma (CTCL), did not induce proliferation in CTCL cell lines, including Hut78, SeAx, and MyLa; rather, CCL18 was found to inhibit the proliferation of both SeAx and MyLa [80]. These data suggest that the biochemical function of CCL18 for proliferation in solid tumors and hematoma might be divergent or tumor/tissue specific. Although its underlying mechanisms are 
still unclear, future anti-tumor treatment should be informed by the contradictory role of CCL18 in tumor progression in order to obtain good therapeutic efficacy.

\subsection{Effects of TAMs on Cancer Cell Invasion and Their Targeted Therapy Based on Proteins}

Tumor invasion, an integral step in distant metastasis, is typically induced by proteins dependent on the crosstalk between TAMs and tumor cells. For instance, Liu et al. found that TAM-derived transforming growth factor- $\beta$ (TGF- $\beta$ ) could upregulate HIF- $1 \alpha$ to increase the tribbles pseudokinase 3 (TRIB3) expression of colorectal cancer (CRC) cells, subsequently activating the $\beta$-catenin/Wnt signaling pathway, and as a result, facilitating the invasion of CRC cells [81]. Similarly, by transwell assay, Fan et al. showed that CD68 ${ }^{+}$ TAMs mainly exhibited the M2 phenotype with a higher expression of TGF- $\beta 1$, and could induce the EMT process and promote the invasive capability of $\mathrm{HCC}$, while performing TGF- $\beta 1$ neutralizing anti-body could attenuate TGF- $\beta 1$ induced EMT, migration, and invasion of HCC [82]. Additionally, in a ESCC model, Okamoto et al. demonstrated that the TAM-derived growth differentiation factor 15 (GDF15) increased the phosphorylation of TGF- $\beta$ RII in ESCC and promoted ESCC invasion, while LY2109761 (a TGF- $\beta$ RI/II inhibitor) could suppress GDF15 dependent reinforcement of ESCC invasion [83]. Together, TGF- $\beta$ and its super family-like GDF15 play a pivotal role in tumor invasion, and the EMT is regarded as an important mechanism in TGF- $\beta$ induced tumor invasion.

Of note, a few targeting GDF15 inhibitors are available and further explorations are still needed to address the underlying mechanisms of GDF15 dependent on tumor invasion.

Further, tumor necrosis factor- $\alpha$ (TNF- $\alpha)$, a pro-inflammatory cytokine secreted by TAMs in the TME, has been found to support tumor invasion. Hagemann et al. observed that the co-culture between macrophages and ovarian or BC cells could induce the activation of the JNK and NF- $\mathrm{B}$ B pathways in a TNF- $\alpha$-dependent manner, subsequently increasing the invasion of tumor cells; further, blocking the activation of JNK and NF- $\mathrm{KB}$ pathways by neutralizing antibodies can abrogate tumor cell invasiveness [84]. Additionally, Cho et al. found that M1 macrophages could secret TNF- $\alpha$, and that the implementation of TNF- $\alpha$ inhibitor, TPCK, could suppress ovarian cancer invasion [85], indicating that M1/M2 macrophage-derived TNF- $\alpha$ promoting cancer invasion is a common event in tumor progression. To support this, in another study, Singh et al. found that macrophagederived TNF- $\alpha$ induced the secretion of TGF- $\beta 1$ in BC cells and then caused the DNA damage in BC cells by activating a survival pathway to deregulate DNA damage and ROS, subsequently leading to an increasing EMT by the upregulation of CREB phosphorylation and vimentin expression, while the neutralization of TNF- $\alpha$ by GolgiPlug (555029) could abrogate BC cell invasion and migration [86]. Interestingly, Watanabe et al. showed that exogenous recombinant TNF- $\alpha$ could induce the secretion of IL- 8 in oral squamous cell carcinoma (OSCC) cells to increase OSCC cell invasion with the degradation of ECM via promoting the release of MMP2/7/9 [87]. In sum, the recombinant and TAM-derived TNF- $\alpha$ plays a promotive role in tumor invasion by various signaling pathways.

Table 2. Targeting proteins in the crosstalk between TAMs and cancer cells.

\begin{tabular}{ccccc}
\hline Ligand & Effector & Tumor & Inhibitor & Anti-Tumor Mechanism \\
\hline IL-10 & & Inhibit the proliferation of cancer cells & Def. & $\begin{array}{c}\text { Decrease IL-10 induced PD-L1 } \\
\text { expression }\end{array}$ \\
\hline IL-10 & PD-L1 & NSCLC & BFD & $\begin{array}{c}\text { Inhibit BMP-6 induced M2 } \\
\text { polarization }\end{array}$ \\
\hline MCAD & STAT3 & RCC & N/A & Reduce LD accumulation in TAMs \\
\hline
\end{tabular}


Table 2. Cont.

\begin{tabular}{|c|c|c|c|c|c|}
\hline Ligand & Effector & Tumor & Inhibitor & Anti-Tumor Mechanism & Ref. \\
\hline $\mathrm{MIF}$ & IL-2 & CRC & NIHIII.D.9 & $\begin{array}{l}\text { Decrease Treg generation } \\
\text { and IL-2 production }\end{array}$ & [90] \\
\hline EGFR & ILT4 & NSCLC & Human ILT4 antibody & $\begin{array}{l}\text { Inhibit TAM recruitment } \\
\text { and M2 polarization }\end{array}$ & {$[91]$} \\
\hline $\mathrm{MK} 2$ & IL-1, IL-6, TNF- $\alpha$ & CRC & PF364402 & $\begin{array}{c}\text { Inhibit IL-1 } \beta, \text { IL-6, } \\
\text { and TNF- } \alpha \text {, expression }\end{array}$ & [92] \\
\hline \multicolumn{6}{|c|}{ Inhibit the invasion of tumor } \\
\hline Lactate & Gpr132 & $\mathrm{BC}$ & $\mathrm{N} / \mathrm{A}$ & $\begin{array}{c}\text { Inhibit lactate uptake and M2 } \\
\text { macrophages activity }\end{array}$ & {$[61]$} \\
\hline IGFBP2 & Fc $\gamma$ RIIB & GBM & Bs-1108R & $\begin{array}{c}\text { Increase CD8+ T and p-CD19+ B } \\
\text { cells and decreases M2 } \\
\text { macrophages }\end{array}$ & [93] \\
\hline S100A8/A9 & MMP2, MMP9 & $\mathrm{LCC}$ & $\mathrm{N} / \mathrm{A}$ & Decrease MMP2 and MMP9 & [94] \\
\hline GS & Glutamine & $\mathrm{N} / \mathrm{A}$ & MSO & $\begin{array}{l}\text { Suppress M2 macrophages, induce } \\
\text { T-cell recruitment }\end{array}$ & [95] \\
\hline ATM & ATR & $\mathrm{BC}$ & Clone 10H11.E12 & Decrease pCREB expression & [86] \\
\hline \multicolumn{6}{|c|}{ Inhibit the angiogenesis of tumor } \\
\hline IL-10/IL-13 & $\mathrm{N} / \mathrm{A}$ & $\mathrm{RCC}$ & Let-7d & $\begin{array}{l}\text { Inhibit intratumoral macrophage } \\
\text { M2 polarization }\end{array}$ & {$[47]$} \\
\hline S100A7 & JAB1 & ESCC & $\mathrm{N} / \mathrm{A}$ & $\begin{array}{c}\text { Inhibit S1007A induced } \\
\text { phosphorylation of ERK and FAK }\end{array}$ & [96] \\
\hline $\mathrm{N} / \mathrm{A}$ & $\mathrm{PI} 3 \mathrm{~K} / \mathrm{Akt} / \mathrm{mTOR}$ & $\mathrm{HCC}$ & Apigenin & Inhibit PI3K/Akt/mTOR pathway & [97] \\
\hline S1PR1 & NLRP3 & $\mathrm{BC}$ & $\mathrm{N} / \mathrm{A}$ & $\begin{array}{c}\text { Inhibit S1PR1 dependent } \\
\text { IL-1 } \beta \text { expression }\end{array}$ & [98] \\
\hline LOX & $\beta 1$ integrin/PYK2 & GBM & BAPN & Decrease TAM-derived SPP1 & [99] \\
\hline \multicolumn{6}{|c|}{ Inhibit the stemness of tumor } \\
\hline$\alpha-K G$ & Jmjd-3 & $\mathrm{N} / \mathrm{A}$ & BPTES & $\begin{array}{l}\text { Suppressed IL-4-induced STAT6 } \\
\text { phosphorylation }\end{array}$ & {$[62]$} \\
\hline LSECtin & BTN3A3 & $\mathrm{BC}$ & $5 \mathrm{E} 08$ & $\mathrm{~N} / \mathrm{A}$ & {$[100]$} \\
\hline CCL8 & Erk1/2 & GBM & SCH772984 & Attenuate pseudopodia formation & {$[101]$} \\
\hline IL-8 & STAT3 & OC & $\mathrm{IL}-8 \mathrm{Ab}$ & $\begin{array}{l}\text { Inhibit STAT3 and increase IL-12, } \\
\text { NO }\end{array}$ & {$[102]$} \\
\hline CBX8 & H3K4me3 & CRC & $\mathrm{N} / \mathrm{A}$ & $\begin{array}{l}\text { Increased the chemosensitivity of } \\
\text { CRC cells }\end{array}$ & {$[103]$} \\
\hline
\end{tabular}

RCC: renal cell carcinoma; CRA: cervical cancer; ESCC: esophageal squamous cell carcinoma; EGF: endothelial growth factor; IGFBP2: insulin-like growth factor binding protein 2; Gpr132: G-protein-coupled receptor 132; PPAR $\gamma$ : peroxisome proliferation-activated receptor- $\gamma ; \alpha$-KG: $\alpha$-ketoglutarate; GS: glutamine synthase; TNF- $\alpha$ : tumor necrosis factor- $\alpha$; TGF- $\beta$ : transforming growth factor- $\beta$; CHA: chlorogenic acid; MMP: matrix metalloproteinase; ERK: extracellular regulated protein kinase; mTOR: mechanistic target of rapamycin; MIF: macrophage migration inhibitory factor; MK2: MAPK-activated protein kinase 2; S1PR1: sphingosine-1-phosphate receptor 1; LOX: lysyl oxidase; LSECtin: liver sinusoidal endothelial cell lectin; CBX8: chromobox protein homolog 8; H3K4me3: histone H3 lysine 4 trimethylation; jmjd-3: Jumanji domain-containing protein D3; Gpr132: G-protein coupled receptor G2A; Fc $\gamma$ RIIB: Fc gamma receptor IIB; PYK2: proline-rich tyrosine kinase 2; NLRP3: NOD-, LRR- and pyrin domain-containing protein 3; MSO: methionine sulfoximine; BPTES: bis-2-(5-phenylacetamido1,3,4-thiadiazol-2-yl)ethyl sulfide; BAPN: beta-Aminopropionitrile monofumarate; BFD: bu fei decoction; MCAD: medium-chain acyl-CoA dehydrogenase; ATM: ataxia telangiectasia mutated; ATR attenuated total reflectance; N/A: not applicable.

\subsection{Effects of TAMs on Angiogenesis and Their Targeted Therapy Based on Proteins}

Tumor angiogenesis refers to abnormal blood vessel formation involving the migration, proliferation, and differentiation of endothelial cells, which is regulated by an extensive variety of angiogenic stimulators and inhibitors. It has been found that TAM-derived VEGF and its receptor are significant factors in promoting tumor angiogenesis. For instance, Joshi et al. provided evidence that revealed that the PTEN/PI3K/AKT signaling pathway could 
increase the hypoxia-induced HIF- $1 \alpha$ and HIF- $2 \alpha$ stability of macrophages to induce the secretion of VEGF for promoting tumor angiogenesis in Lewis lung carcinoma [104]. By the establishment of the BC model, Dong et al. showed that M2 macrophage derived VEGF could enhance the expression of prostate cancer-associated transcript 6 (PCAT6) and upregulate VEGFR-2 expression simultaneously by sponging miR-4723-5p, therefore reinforcing the tumor angiogenesis through the activation of VEGFR-2/Akt/mTOR signal axis [105]. In our preliminary study, we depleted macrophages in SCC models and found downregulated TGF- $\beta 1$ and VEGFA in tumor cells [63], demonstrating that TGF- $\beta 1$ reduction could be sufficient to reduce VEGFA-dependent angiogenesis after TAM ablation. Recently, the applications of VEGF and VEGFR inhibitors, including bevacizumab, sorafenib, and sunitinib, have been found to attenuate tumor angiogenesis by inducing endothelial cell apoptosis [106]. Tumor vasculature is surrounded by less smooth muscle cells, sinusoidal vessel plexuses and pericytes, missing lymphatic drainage and adrenergic innervation, erratically basal membrane, and interrupted endothelial lining, it also exhibits complex branching patterns and negatively influences drug delivery [107-111]; therefore, the exploring of the downstream pathway after VEGF stimulation might be a promising strategy for exploiting many more targets in order to overcome the above barriers in anti-tumor therapies.

Macrophage-derived secreted phosphoprotein 1 (SPP1) could also promote tumor angiogenesis in the phosphatase and tensin homolog (PTEN) deficiency GBM model [99]. In another study, Wenes et al. found that regulated in development and DNA damage 1 (REDD1), a negative regulator of mTOR, was upregulated in hypoxic TAMs, and that mTOR inhibition in TAMs could reduce an excessive angiogenic response, while blocking glycolysis by reducing glucose uptake, consequently inducing the formation of abnormal vascular [112]. To further explore the underlying mechanism, they provided evidence showing that REDD1 depletion could rescue the activation of mTOR and increase the glycolysis and/or glucose uptake of TAMs, subsequently competitively suppressing endothelial cells in a glucose-dependent manner and promoting the tumor vessel normalization [112]. Conversely, in HCC, Chen et al. reported that, when mTOR in macrophages was inhibited, STAT3 decreased the secretion of both IL-10 and IL-12 and could impede angiogenesis in vivo [113]. This suggests the dual role of $\mathrm{mTOR}$ in tumor angiogenesis; therefore, targeted mTOR strategies for attenuating tumor angiogenesis should be based on the further exploration of the underlying mechanism and the optimization of the anti-tumor function.

3.4. Effects of TAMs on Cancer Stemness and Drug Resistance, and Their Targeted Therapy Based on Proteins

Stemness, which confers proliferative ability on tumor cells, allows few tumor cells to develop and form visible tumors, and could promote tumorigenesis, therapeutic resistance, tumor recurrence, and dissemination [114,115]. TAM-mediated cancer stemness could be modulated by diverse proteins and related signaling pathways. For example, Liu et al. found that the LSECtin expressed on TAMs could interact with its receptor butyrophilin subfamily 3, member A3 (BTN3A3) and enhance the stemness of BC cells; further, when applying the anti-BTN3A3 antibody, 5E08, the stemness of BC cells could be attenuated [100]. Meanwhile, the activation of the Akt and $\beta$-catenin signaling pathway could induce macrophage-derived soluble glycoprotein NMB (GPNMB), which could bind with the CD44 receptor and then trigger crucial survival pathways, followed by increasing the IL-33, IL-1RL1 expression, p38, STAT3, STAT5 phosphorylation, and NF- $\mathrm{BB}$ activation, which would ultimately promote cancer stemness [116,117]. In our preliminary study, we found that targeting CD44 could decrease macrophage-associated PI3K/4EBP1/SOX2 signal for suppressing cancer stemness in head and neck cancer [118]. Similarly, when decreasing CD44 expression by the application of foretinib, the stemness of gastric cancer cells would be attenuated [119]. These data suggest that the activation of the $\beta$-catenin signaling pathway might be the key step in TAM-dependent tumor stemness, while both membrane proteins and soluble proteins are involved in this process. Other proteins, such as GPNMB and LSECtin, also exhibit potential to be used as targeted proteins in anti-tumor therapies. 
Recently, new findings indicate that TAMs could mediate the therapeutic resistance of tumors in a protein-dependent manner. For instance, Li et al. provided evidence demonstrating that TAM-derived CCL2 could activate the PI3K/Akt/mTOR signaling pathway, subsequently promoting the acquirement of tamoxifenresistance in BC cells, and when applying Bindarit, a CCL2 synthesis inhibitor, the secretion of CCL2 and the phosphorylation of both Akt and mTOR could be significantly attenuated [120]. Additionally, in the CSF-1R inhibition therapy of GBM, Quail et al. found that the PI3K cascade can also be activated by TAM-derived insulin-like growth factors1 (IGF-1), as a result, promoting tumor cells to be resisted to BLZ945, a type of CSF-1R inhibitor, and the application of PI3K inhibitor (BKM120) could rescue the chemosensitivity of GBM in CSF-1R inhibition therapy [121]. These data suggest that PI3K might play a pivotal role in generating the drug resistance of tumors during therapies. Interestingly, the source of biomolecules that contribute to drug resistance is not always from TME; some side effects of the drugs in tumor therapies also induce drug resistance directly or indirectly. To support this, in the $\mathrm{BC}$ model, Liu et al. showed that bevacizumab-induced $\mathrm{F}_{\mathrm{C}} \gamma$ receptor could interact with TLR4 and induce the M2b macrophages polarization; subsequently, the upregulation of indoleamine 2,3-dioxygenase 1 (IDO1) could be mediated in a TNF- $\alpha$-dependent manner. Finally, the macrophage-derived TNF- $\alpha$ and IDO1 could induce drug resistance, and the neutralization of TNF- $\alpha$ could reverse bevacizumab resistance significantly [122]. Taken together, TAMs engage in crosstalk with tumor cells via diverse proteins and pathways to promote the proliferation, invasion, angiogenesis, stemness, and drug resistance of tumor cells, and these proteins hold great potential to be targeted in anti-tumor therapy (Table 3).

Table 3. TAM-associated factors and their targeted roles in cancers.

\begin{tabular}{|c|c|c|c|c|c|}
\hline Factor & Cancer & Recipient & Influence on Tumor & Biochemical Mechanism & Ref. \\
\hline \multicolumn{6}{|c|}{ Cytokines } \\
\hline $\mathrm{IL}-1 \beta$ & $\mathrm{HCC}$ & Tumor & Promote tumor migration & $\begin{array}{l}\text { NLRP3 dependent } \\
\text { FAO/ROS/IL-1 } \beta \text { axis }\end{array}$ & {$[123]$} \\
\hline \multirow[t]{4}{*}{ IL-6 } & CRC & Tumor & $\begin{array}{l}\text { Promote tumor } \\
\text { invasion and migration }\end{array}$ & $\begin{array}{c}\text { Regulate } \\
\text { JAK2/STAT3/miR-506-3p/FoxQ1 } \\
\text { axis }\end{array}$ & {$[124]$} \\
\hline & CRC & Tumor & $\begin{array}{l}\text { Promote tumor invasion } \\
\text { and migration }\end{array}$ & $\begin{array}{l}\text { Activate the Wnt } / \beta \text {-catenin } \\
\text { pathway }\end{array}$ & {$[125]$} \\
\hline & $\mathrm{BC}$ & TAMs & Promote tumor development & Activate the gp130/STAT3 pathway & [126] \\
\hline & $\mathrm{HCC}$ & Tumor & $\begin{array}{l}\text { Promote tumor invasion } \\
\text { and metastasis }\end{array}$ & $\begin{array}{l}\text { Activate IL-6/ERK and STAT3 } \\
\text { pathway }\end{array}$ & {$[127]$} \\
\hline IL-8 & OC & Tumor & Promote tumor stemness & Activate the IL-8/STAT3 pathway & {$[102]$} \\
\hline \multirow[t]{3}{*}{ IL-10 } & PC & Tumor & Promote tumor migration & $\begin{array}{c}\text { Activate TLR4/IL-10 to express } \\
\text { MMP2 and MMP9 }\end{array}$ & [128] \\
\hline & NSCLC & Tumor & Promote tumor invasion & Induce PD-L1 expression & {$[88]$} \\
\hline & $\mathrm{BC}$ & DC & Attenuate $\mathrm{CD}^{+} \mathrm{T}$-cell cytotoxicity & Decrease IL-12 expression & [129] \\
\hline \multirow[t]{2}{*}{ IL-23 } & $\mathrm{KC}$ & Treg & Promote tumor immune evasion & $\begin{array}{l}\text { Increase IL-10, TGF- } \beta \text { expression, } \\
\text { and Treg activity }\end{array}$ & {$[130]$} \\
\hline & $\mathrm{BC}$ & TAMs & Promote tumor angiogenesis & $\begin{array}{l}\text { Increase IL-10, TGF- } \beta, \text { VEGF } \\
\text { expression }\end{array}$ & {$[131]$} \\
\hline IL-34 & CRC & TAMs & Promote tumor growth & Increase IL-6 expression & [132] \\
\hline
\end{tabular}


Table 3. Cont.

\begin{tabular}{|c|c|c|c|c|c|}
\hline Factor & Cancer & Recipient & Influence on Tumor & Biochemical Mechanism & Ref. \\
\hline \multicolumn{6}{|c|}{ Chemokines } \\
\hline CCL2 & $\mathrm{BC}$ & Tumor & Promote drug resistance & $\begin{array}{l}\text { Activate the PI3K/Akt/mTOR } \\
\text { pathway }\end{array}$ & {$[120]$} \\
\hline CCL5 & CRC & Tumor & Promote tumor immune escape & $\begin{array}{c}\text { Activate the } \\
\text { p65/STAT3-CSN5-PD-L1 pathway }\end{array}$ & {$[133]$} \\
\hline CCL8 & GBM & Tumor & $\begin{array}{l}\text { Promote tumor invasion } \\
\text { and stemness }\end{array}$ & Activate the ERK1/2 pathway & {$[101]$} \\
\hline CXCL12 & CRC & Tumor & Promote tumor angiogenesis & Activate the MK2 pathway & {$[134]$} \\
\hline \multirow[t]{2}{*}{ CCL18 } & $\mathrm{BC}$ & Tumor & $\begin{array}{l}\text { Promote tumor invasion } \\
\text { and metastasis }\end{array}$ & $\begin{array}{c}\text { Activate the } \\
\text { AnxA2/PI3K/Akt/GSK3 } \beta / \text { Snail } \\
\text { pathway }\end{array}$ & {$[135]$} \\
\hline & $\mathrm{BC}$ & Tumor & Promote tumor metastasis & $\begin{array}{l}\text { Activate the PKC } \delta / S T A T 3, N F-\kappa B \\
\text { pathway }\end{array}$ & {$[136]$} \\
\hline CCL20 & CRC & Treg & Promote Treg recruitment & CCL20/CCR6 couple & [137] \\
\hline CCL22 & NSCLC & Treg & Promote Treg recruitment & Increase IL-8 expression & {$[138]$} \\
\hline \multicolumn{6}{|c|}{ Others } \\
\hline $\mathrm{TNF}-\alpha$ & $\mathrm{BC}$ & Tumor & Promote tumor EMT and migration & $\begin{array}{c}\text { Increase cAMP and CREB } \\
\text { expression }\end{array}$ & {$[86]$} \\
\hline TGF- $\beta$ & CRC & TAMs & Promote tumor proliferation & Increase RGC-32, COX2 expression & [139] \\
\hline LSECtin & $\mathrm{BC}$ & Tumor & Promote tumor stemness & $\mathrm{N} / \mathrm{A}$ & [100] \\
\hline \multirow[t]{2}{*}{ MIF } & CRC & $\mathrm{N} / \mathrm{A}$ & Promote tumor growth & Increase Tregs generation & {$[90]$} \\
\hline & PDAC & $\mathrm{N} / \mathrm{A}$ & Promote tumor metastasis & $\begin{array}{c}\text { Activate AKT, ERK, and express } \\
\text { cyclin-D1, MMP2 }\end{array}$ & {$[140]$} \\
\hline Xist & $\mathrm{BC}$ & TAMs & Promote tumor proliferation & $\begin{array}{l}\text { IncRNA-Xist } / \mathrm{miR}-101- \\
\text { 3p/KLF6/C/EBP } \alpha \\
\text { axis }\end{array}$ & {$[141]$} \\
\hline ROS & CRC & $\mathrm{N} / \mathrm{A}$ & Promote tumor proliferation & Activate NF-kB, AP-1, EGR-1 & {$[142]$} \\
\hline MCP-1 & CRC & Tumor & Promote tumor growth, invasion & Activate the MK2 pathway & [92] \\
\hline BMP-6 & PC & TAMs & $\begin{array}{c}\text { Promote tumor angiogenesis and } \\
\text { growth }\end{array}$ & $\begin{array}{l}\text { Increase IL-1a expression through } \\
\text { Smad1, NF-kB }\end{array}$ & [143] \\
\hline GPR35 & CRC & Tumor & $\begin{array}{c}\text { Promote tumor angiogenesis } \\
\text { and growth }\end{array}$ & $\begin{array}{c}\mathrm{Na} / \mathrm{K} \text {-ATPase-dependent ion } \\
\text { pumping }\end{array}$ & {$[144]$} \\
\hline CD206 & CRC & $\mathrm{N} / \mathrm{A}$ & Attenuate $\mathrm{CD}^{+} \mathrm{T}$-cell cytotoxicity & Inhibit CD45 phosphatase activity & [145] \\
\hline Oct4 & $\mathrm{LC}$ & TAMs & Promote tumor growth & Increase M-CSF expression & [146] \\
\hline Chi3L1 & $\mathrm{BC}$ & Tumor & Promote tumor metastasis & $\begin{array}{c}\text { Activate the } \\
\text { CHI3L1/IL-13R } \alpha 2 / \text { ERK/JNK axis }\end{array}$ & {$[147]$} \\
\hline RACK1 & OSCC & TAMs & Promote tumor development & Regulate NF-кB pathway & {$[148]$} \\
\hline GPNMB & $\mathrm{BC}$ & Tumor & Promote tumor stemness & Increase IL-33, CD44 expression & [116] \\
\hline S100A9 & $\mathrm{HCC}$ & Tumor & Promote tumor stemness & Activate AGER/NF- $\mathrm{kB}$ axis & [149] \\
\hline
\end{tabular}

OSCC: oral squamous cell carcinoma; KC: kidney cancer; COX2: cyclooxygenase 2; CtsZ: cathepsin Z; FR $\beta$ : folate receptor-beta; LCN-2: lipocalin 2; Xist: X inactive-specific transcript; VEGFR: vascular endothelial growth factor receptor; ROS: reactive oxygen species; MCP-1: monocyte chemoattractant protein-1; BMP-6: bone morphogenetic protein 6; GPR35: G protein-coupled receptor 35; Oct4: octamer-binding transcription factor 4; CTHRC1: collagen triple helix repeats containing 1; Chi3L1: chitinase 3-like protein 1; CD206: mannose receptor; RACK1: receptor for activated C kinase 1; GPNMB: glycoprotein NMB; IL-37: interleukin $37 ; \alpha_{\mathrm{m}} \beta_{2}: \alpha_{\mathrm{m}} \beta_{2}$ integrin; CREB: cAMP response-binding protein; $\mathrm{N} / \mathrm{A}$ : not applicable.

\section{Targeting Proteins of TAMs in the Regulation of Tumor Immune Responses}

TAMs serve an integral role in the alternation of the TME immune landscape and the establishment of anti-tumor immunity suppression. TAMs could engage in crosstalk with multiple immune cells, including CD8 ${ }^{+} \mathrm{T}$ cells, B cells, Tregs, dendritic cells (DCs), and natural killer (NK) cells, in a protein- and/or signaling-pathway-dependent manner (Figure 3). Therefore, to inhibit the immunosuppressive functions of TAMs, an extensive 
variety of studies have focused on targeting the effective proteins and pathways in the crosstalk between TAMs and immune cells.
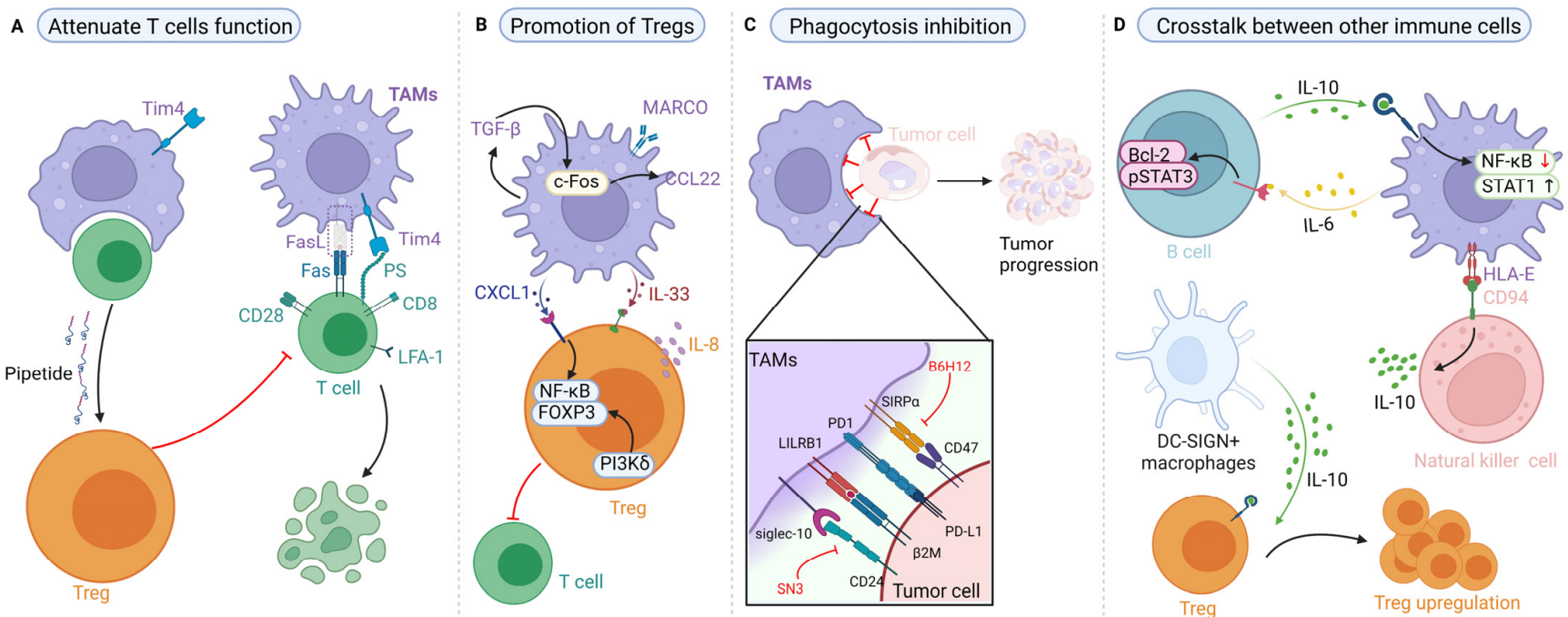

Figure 3. Targeting the crosstalk between TAMs and immune cells. (A) Tim4 and fasL expressed on the surface of TAMs could bind with phosphatidylserine and Fas on T cells, respectively, then inducing the apoptosis of T cells and suppressing the function of T cells. Apoptotic T cells could be phagocyted by TAMs, subsequently releasing pipetide to activate Treg, as a result, inhibiting the function of T cells. (B) TAM-derived chemokines and cytokines, such as TGF- $\beta$, CCL22, CXCL1, and IL-33, could upregulate the activity of Treg via the NF- $\mathrm{B}$ and $\mathrm{PI} 3 \mathrm{~K} \delta$ signaling pathways, then suppressing the function of T cells. (C) The SIRP $\alpha$, PD-1, LILRB1, and siglec-10 expressed on the surface of TAMs could bind with CD47, PD-L1, $\beta 2 \mathrm{M}$, and CD24, respectively, then attenuating the phagocytosis of TAMs. Applying SN3 and B6H12 to block SIRP $\alpha / C D 47$ axis and siglec-10/CD24 axis, respectively, could reverse the inhibition of phagocytosis. (D) TAM crosstalk with other immune cells, such as B cells and natural killer cells, via the release of IL-6, IL-10, and the binding between HLA-3 and CD94. Even the DC-SIGN+ macrophages could express a high level of IL-10 to upregulate Tregs. BCL2: B-cell lymphoma 2; LFA-1: lymphocyte function-associated antigen-1; MARCO: macrophage receptor with collagenous structure; c-Fos: a proto-oncogene regulating the transcription of many genes.

\subsection{Effects of TAMs on T-Cell Immunity and Their Targeted Therapy Based on Proteins}

TAMs, especially M2 macrophages, are characterized by an impaired antigen presentation ability in the TME, the expression of associated proteins, the upregulation of immunosuppressive mediators, and the downregulation of proinflammatory cytokines; as a result, they can attenuate T-cell-mediated adaptive immune response [150,151]. Moreover, Miller et al. showed that Fas expressed on $\mathrm{CD}^{+} \mathrm{T}$ cells, binding with the FasL in macrophages, could activate intratumoral macrophages via the interferon-gamma (IFN$\gamma)$ and Fas/FasL axis, leading to a limitation of the immunosurveillance of intraocular tumors [152]. However, in another study on colorectal cancer with liver metastases, Yu et al. found that the hepatic $\mathrm{CD} 11 \mathrm{~b}^{+} / \mathrm{F} 4 / 80^{+}$macrophages express FasL highly when bearing liver tumors and tumor-specific T cells were siphoned into the liver in an integrindependent manner, subsequently leading to the activation of the extrinsic apoptosis of $\mathrm{Fas}^{+} \mathrm{T}$ cells by the Fas-FasL pattern for promoting tumor progression [153]. This suggests the paradoxical role of the Fas/FasL axis in tumor-associated immune and relevant targeting therapies; the biochemical function of the Fas/FasL axis might be tissue specific. An alternative hypothesis, which is supported by the observation that studies on colorectal cancer without liver metastases have not reported altered T-cell numbers [153], is that liver metastasis might mediate immune function by the Fas/FasL axis, which prevents systemic anti-tumor immunity, and this effect should be recognized in anti-tumor therapies, especially for cancers with or without liver metastasis. 
Another special protein expressed on the TAMs' membrane is Tim4. For instance, Chow et al. found that TAMs in ovarian carcinoma can be divided into two subsets, including Tim $4^{+}$TAMs (F4/80 ${ }^{\text {high }}$ MHC-II $\left.^{\text {low }}\right)$ and Tim4- TAMs (F4/80 ${ }^{\text {low }}$ MHC-II ${ }^{\text {high }}$ ) [10]. Further, they suggested that Tim $4^{+}$on TAMs could combine directly with the phosphatidylserine in $\mathrm{CD}^{+} \mathrm{T}$ cells, subsequently attenuating its cytotoxicity and proliferation for promoting metastasis [10,154]. In another ovarian model, Xia et al. found that the immunosuppressive function of Tim $4^{+}$TAMs was mainly mediated by autophagy and the FAK family-interacting protein of $200 \mathrm{kDa}$ (FIP200); further, they found that a deficiency in FIP200 could both result in Tim4 ${ }^{+}$TAMs $^{\prime}$ death in the TME and promote T-cell-mediated anti-tumor immune response via the upregulation of ROS [155]. Similar to these findings, in our preliminary data, we also found that TAM ablation inhibited tumor growth, and that clodronate treatment for TAM depletion could increase the number of CD8 ${ }^{+} \mathrm{T}$ cells in SCC tumors [45]. In summary, this evidence suggests that TAMs could affect T-cell function by the membrane proteins; however, only a few inhibitors, such as targeting Tim4, have been made available to date. One of the reasons for this is that TAMs are highly heterogeneous stromal cells and their membrane proteins, such as Tim4, not only express on TAMs, but also on dendritic cells [156], B cells [156] and fibroblasts [157]; thus, the discovery of the heterogeneity of TAMs has revealed a remarkably complex and diverse portrait.

\subsection{Effects of TAMs on Regulatory T Cells (Tregs) and Their Targeted Therapy Based on Proteins}

Tregs, a specialized subset of $\mathrm{CD}^{+} \mathrm{T}$ cells identified as $\mathrm{CD}^{+} / \mathrm{CD}^{+} / \mathrm{CD}^{2} 5^{+} / \mathrm{FoxP}^{+}$ cells, act to suppress the immune response in maintaining immune homeostasis and self-tolerance. TAMs engage in crosstalk with Tregs by an extensive variety of proteins and associated pathways (Figure 3B). For instance, Fleur et al. provided evidence that applying a neutralizing antibody to inhibit the macrophage receptor with a collagenous structure (MARCO) in TAMs could downregulate the activation of Tregs [158]. In another study, Li et al. found that the CXCL1 expressed by TAMs could be recognized by CXCR2 of peripheral naive $\mathrm{CD}^{+} \mathrm{T}$ cells, subsequently recruiting those cells into the TME and inducing their differentiation into Tregs via the NF- $\mathrm{B}$ /FoxP3 pathway in BC [20]. Using aiduqing can inhibit Tregs activity induced by TAM-derived CXCL1 and partly reverse the immunosuppressive TME [20]. Importantly, Wang et al. provided data that demonstrated that autocrine TGF- $\beta$ stimulates TAMs to secret CCL22 via c-Fos to promote the recruitment of Tregs, and that the anti-CCL22 antibody could attenuate the recruitment of Tregs [138]. As feedback, the recruited Tregs could secrete IL-8 into the TME, and the exogenous IL- 8 could induce the production of TGF- $\beta$ in TAMs [138]. It suggests that there is positive feedback in the TAM-dependent recruitment of Tregs and that the establishment of the immunosuppressive TME might be not only induced by the biochemical function of TAMs, but also reinforced by the interaction between TAMs and immune cells, such as Tregs.

To further investigate the bilateral association between TAMs and Tregs, Gyori et al. showed that the depletion of either CSF1R ${ }^{+}$TAMs or PI3K $\delta$-driven Foxp3 ${ }^{+}$Tregs in the immunosuppressive TME of colorectal cancer could induce the upregulation of the other and limit the therapeutic effect [159], suggesting that TAMs and Tregs serve as a couple of compensatory factors and maintain number homeostasis. Furthermore, after being recruited into the TME, Tregs could suppress the IFN- $\gamma$ secretion of CD8 ${ }^{+} \mathrm{T}$ cells and attenuate the inhibition of sterol regulatory element-binding protein 1 (SREBP1) in immunosuppressive M2 macrophages, subsequently facilitating fatty acid synthesis in M2 macrophages [160], which indicates that Tregs maintain the metabolic fitness and survival of M2 macrophages indirectly. Of note, the SREBP1 inhibitor (Fatostatin) failed to elicit an effective anti-tumor response effectively [160], suggesting that the inhibition of SREBP1 might not affect Tregs, which have already been recruited into TME and permanently exert an immunosuppressive function. Taken together, Tregs serve as TAM-mediated immunosuppressive cells in TME, and the feedback between TAMs and Tregs, especially the IL-8/TGF- $\beta$ axis, plays a pivotal role in the establishment of the immunosuppressive TME. 


\subsection{Effects of TAM-Mediated Phagocytosis and Their Targeted Therapy Based on Proteins}

Macrophage-mediated phagocytosis, characterized by the uptake of macromolecules and larger particles through the membrane protrusions, can be triggered by diverse receptor-ligand interactions to clear pathogens, cellular fragments, and even dead cells for the initiation of innate immune response [161,162]. Interestingly, various signaling pathways and proteins in tumor cells could attenuate the innate immune function of TAMs (Figure 3C). For instance, Majeti et al. found that cluster of differentiation 47 (CD47), a kind of "do not eat me single", expressed on the surface of tumor cells can protect tumor cells from phagocytosis by binding to signal regulatory protein alpha (SIRP $\alpha)$ in TAMs and that its inhibitor (B6H12.2) could enable the phagocytosis of acute myeloid leukemia cells in a mouse model [163]. Furthermore, Willingham et al. held that CD47 was a commonly expressed marker on all kinds of cancer cells, and that each human solid tumor cell requires CD47 to be expressed on the surface in order to evade phagocytic innate immune surveillance [164]. Of note, the inhibition of the CD47-SIRP $\alpha$ signaling pathway by rituximab alone in patients of follicular lymphoma led to anemia, and this side effect could be mitigated by 5F9 (a macrophage immune checkpoint inhibitor) [165,166], illustrating that combining rituximab for blocking CD47 and 5F9 for attenuating anemia could be an example of optimized antibody-dependent cellular phagocytosis. Since the swallowed tumor cells might be degraded by lysosomes in TAMs, to keep tumor cells alive, we previously hypothesized that TAMs phagocytize tumor cells via semi-phagocytosis to evade elimination by the immune system and avoid degradation by the endosomal/lysosomal system for distant metastasis [167].

Additionally, other proteins, including programed cell death receptor-1 (PD-1), leukocyte immunoglobulin-like receptor B1 (LILRB1), and CD24, expressed on the surface of TAMs and their receptors, could suppress TAM-mediated phagocytosis (Figure 3C). For instance, Gordon et al. found that the PD-1 expressed on the surface of TAMs could bind with the PD-L1, which exists on the membrane of colon carcinoma cells, subsequently attenuating the phagocytosis ability of TAMs [168], suggesting that the PD-1/PD-L1 axis not only suppresses the anti-tumor function of cytotoxic T cells, but also inhibits the phagocytosis of macrophages. In another study, Barkal et al. verified that cancer cells could express MHC class I component $\beta 2$-microglobulin $(\beta 2 \mathrm{M})$ on their surface and $\beta 2 \mathrm{M}$ could bind with leukocyte immunoglobulin-like receptor subfamily B member 1 (LILRB1), which exists on the surfaces of TAMs, subsequently protecting cancer cells from the phagocytosis of TAMs [169]. Specifically inhibiting the MHC class I/LILRB1 axis has been found to improve the phagocytosis of TAMs, subsequently exerting an anti-tumor effect $[169,170]$. Moreover, CD24 derived from tumor cells can interact with the inhibitory receptor sialic-acid-binding LG-like lectin 10 (siglec-10), which is highly expressed on the surface of TAMs, as a result, promoting the immune evasion and attenuating the phagocytosis of TAMs [171]. Inhibiting CD24 via clone SN3 increased the phagocytosis of TAMs and suppressed triple-negative BC progression [171]. In summary, the phagocytic inhibition of TAMs might be mediated by various proteins, and the targeting of one of them alone could exert a limited anti-tumor effect for the existence of alternative mechanisms, and combining with two or more kinds of drugs to target multiple proteins simultaneously might be an effective anti-tumor strategy.

\subsection{Effects of TAMs on Other Immune Cells and Their Targeted Therapy Based on Proteins}

Other immune cells, including B cells and NK cells, also engage in crosstalk with TAMs, and the proteins involved in the crosstalk have the potential to be targeted for anti-cancer therapy (Figure 3D). For instance, in a mouse model, Wong et al. provided evidence showing that IL-10 secreted by B cells promoted M2 polarization of TAMs via the downregulation of the NF- $\mathrm{KB}$ signaling pathway and the upregulation of the STAT1 signaling cascade in TAMs, subsequently promoting B16 melanoma progression [172]. Furthermore, human leukocyte antigen (HLA)-E expressed on the surface of TAMs could bind with CD94 on the membrane of NK cells to promote the release of IL-10 [173]. Although there is little evidence regarding the crosstalk between TAMs and DC cells, Liu et al. found 
that gastric cancer cells could induce TAMs to become DC-SIGN ${ }^{+}$macrophages and express a high level of IL-10 in order to upregulate Tregs [174]. Together, this evidence suggests that IL-10 plays a pivotal role in the crosstalk between TAMs and immune cells during the tumor-associated immune response, and IL-10 maintains a potent target potential in anti-tumor therapies.

\section{Conclusions and Future Perspectives}

Currently, as summarized above, promising strategies targeting the proteins of TAMs have been developed in both in vitro and in vivo studies. Since TAMs play a paradoxical role in the TME, blocking TAM-maintained tumor promotion and taking advantage of their anti-tumor effect might be promising target strategies. Targeting TAMs in order to decrease the number of interleukins, including IL-4, IL-10, and IL-13, and the number of chemokines, such as CCL2 and CCL5, is a potential candidate for inhibiting TAM polarization and recruitment [175-177]. The selective elimination of tumor-promoting TAM subsets, such as M2 macrophages, or their repolarization from M2 to M1 to become anti-tumor elements might be effective therapeutic approaches. A direct anti-tumor strategy for targeting proteins in TAMs is blocking their crosstalk with tumor cells. For instance, IL-6 and IL-10 could promote cancer cell proliferation directly or indirectly $[89,178]$ and TGF- $\beta$ plays a pivotal role in tumor invasion [179]. Another strategy based on the receptor-ligand pattern aims at increasing immune responses through T cells, Tregs, and B cells, for instance. However, because of the highly heterogeneous nature of TAMs, the same or different types of proteins that are commonly targeted in TAMs and tumor cells might optimize the therapeutic efficacy and attenuate side effects. Macrophage-associated targeted approaches have already entered clinical practice [180]. Further works are also needed to explore the heterogeneity of TAMs in the TME, and they should aim at discovering novel immune cascades and nanomaterials based on the proteins of TAMs for therapeutic targets to produce superior antitumor effects and fewer side effects.

Author Contributions: F.W. and H.Z. conceived and designed the study. D.W. drafted the manuscript. D.W., J.M., J.Y., X.L. and F.W. searched and reviewed the literature, and created the figures and tables. All of the authors critically reviewed and revised the manuscript. All authors have read and agreed to the published version of the manuscript.

Funding: This research was funded by the National Natural Science Foundation of China (No. 82002884 and 82071124), the National Key Research and Development Program of China (2020YFA0714001), the Science and Technology Program of Chengdu City (No. 2021-YF05-02031-SN and 2019-YF05-01151$\mathrm{SN})$, and the Undergraduate Innovation and Entrepreneurship Training Program of Sichuan University (No. 2022120939).

Institutional Review Board Statement: Not applicable.

Informed Consent Statement: Not applicable.

Data Availability Statement: Not applicable.

Acknowledgments: The figures were created with BioRender.com, accessed on 29 November 2021.

Conflicts of Interest: The authors declare no conflict of interest.

\section{References}

1. Cassetta, L.; Pollard, J.W. Targeting macrophages: Therapeutic approaches in cancer. Nat. Rev. Drug Discov. 2018, 17, 887-904. [CrossRef]

2. Wang, W.; Marinis, J.M.; Beal, A.M.; Savadkar, S.; Wu, Y.; Khan, M.; Taunk, P.S.; Wu, N.; Su, W.; Wu, J.; et al. RIP1 Kinase Drives Macrophage-Mediated Adaptive Immune Tolerance in Pancreatic Cancer. Cancer Cell 2018, 34, 757-774. [CrossRef] [PubMed]

3. Qiu, S.-Q.; Waaijer, S.J.H.; Zwager, M.C.; de Vries, E.G.E.; van der Vegt, B.; Schröder, C.P. Tumor-associated macrophages in breast cancer: Innocent bystander or important player? Cancer Treat. Rev. 2018, 70, 178-189. [CrossRef] [PubMed]

4. Li, X.; Liu, R.; Su, X.; Pan, Y.; Han, X.; Shao, C.; Shi, Y. Harnessing tumor-associated macrophages as aids for cancer immunotherapy. Mol. Cancer 2019, 18, 177. [CrossRef] [PubMed] 
5. Yu, A.L.; Gilman, A.L.; Ozkaynak, M.F.; London, W.B.; Kreissman, S.G.; Chen, H.X.; Smith, M.; Anderson, B.; Villablanca, J.G.; Matthay, K.K.; et al. Anti-GD2 antibody with GM-CSF, interleukin-2, and isotretinoin for neuroblastoma. N. Engl. J. Med. 2010, 363, 1324-1334. [CrossRef]

6. Horwitz, S.M.; Koch, R.; Porcu, P.; Oki, Y.; Moskowitz, A.; Perez, M.; Myskowski, P.; Officer, A.; Jaffe, J.D.; Morrow, S.N.; et al. Activity of the PI3K- $\delta, \gamma$ inhibitor duvelisib in a phase 1 trial and preclinical models of T-cell lymphoma. Blood 2018, 131, 888-898. [CrossRef]

7. Hodi, F.S.; Lawrence, D.; Lezcano, C.; Wu, X.; Zhou, J.; Sasada, T.; Zeng, W.; Giobbie-Hurder, A.; Atkins, M.B.; Ibrahim, N.; et al Bevacizumab plus ipilimumab in patients with metastatic melanoma. Cancer Immunol. Res. 2014, 2, 632-642. [CrossRef]

8. Vitale, I.; Manic, G.; Coussens, L.M.; Kroemer, G.; Galluzzi, L. Macrophages and Metabolism in the Tumor Microenvironment. Cell Metab. 2019, 30, 36-50. [CrossRef]

9. Shono, K.; Yamaguchi, I.; Mizobuchi, Y.; Kagusa, H.; Sumi, A.; Fujihara, T.; Nakajima, K.; Kitazato, K.T.; Matsuzaki, K.; Saya, H.; et al. Downregulation of the CCL2/CCR2 and CXCL10/CXCR3 axes contributes to antitumor effects in a mouse model of malignant glioma. Sci. Rep. 2020, 10, 15286. [CrossRef]

10. Chow, A.; Schad, S.; Green, M.D.; Hellmann, M.D.; Allaj, V.; Ceglia, N.; Zago, G.; Shah, N.S.; Sharma, S.K.; Mattar, M.; et al. Tim-4 cavity-resident macrophages impair anti-tumor CD8 T cell immunity. Cancer Cell 2021, 39, 973-988. [CrossRef]

11. Ge, Z.; Ding, S. The Crosstalk Between Tumor-Associated Macrophages (TAMs) and Tumor Cells and the Corresponding Targeted Therapy. Front. Oncol. 2020, 10, 590941. [CrossRef] [PubMed]

12. Chen, Y.; Song, Y.; Du, W.; Gong, L.; Chang, H.; Zou, Z. Tumor-associated macrophages: An accomplice in solid tumor progression. J. Biomed. Sci. 2019, 26, 78. [CrossRef] [PubMed]

13. Yeung, O.W.H.; Lo, C.-M.; Ling, C.-C.; Qi, X.; Geng, W.; Li, C.-X.; Ng, K.T.P.; Forbes, S.J.; Guan, X.-Y.; Poon, R.T.P.; et al Alternatively activated (M2) macrophages promote tumour growth and invasiveness in hepatocellular carcinoma. J. Hepatol. 2015, 62, 607-616. [CrossRef] [PubMed]

14. Franklin, R.A.; Liao, W.; Sarkar, A.; Kim, M.V.; Bivona, M.R.; Liu, K.; Pamer, E.G.; Li, M.O. The cellular and molecular origin of tumor-associated macrophages. Science 2014, 344, 921-925. [CrossRef] [PubMed]

15. Nie, Y.; Huang, H.; Guo, M.; Chen, J.; Wu, W.; Li, W.; Xu, X.; Lin, X.; Fu, W.; Yao, Y.; et al. Breast Phyllodes Tumors Recruit and Repolarize Tumor-Associated Macrophages via Secreting CCL5 to Promote Malignant Progression, Which Can Be Inhibited by CCR5 Inhibition Therapy. Clin. Cancer Res. 2019, 25, 3873-3886. [CrossRef]

16. Linde, N.; Casanova-Acebes, M.; Sosa, M.S.; Mortha, A.; Rahman, A.; Farias, E.; Harper, K.; Tardio, E.; Reyes Torres, I.; Jones, J.; et al Macrophages orchestrate breast cancer early dissemination and metastasis. Nat. Commun. 2018, 9, 21. [CrossRef] [PubMed]

17. Mu, J.; Sun, P.; Ma, Z.; Sun, P. BRD4 promotes tumor progression and NF-кB/CCL2-dependent tumor-associated macrophage recruitment in GIST. Cell Death Dis. 2019, 10, 935. [CrossRef]

18. Hsu, Y.-L.; Hung, J.-Y.; Tsai, Y.-M.; Tsai, E.-M.; Huang, M.-S.; Hou, M.-F.; Kuo, P.-L. 6-shogaol, an active constituent of dietary ginger, impairs cancer development and lung metastasis by inhibiting the secretion of CC-chemokine ligand 2 (CCL2) in tumor-associated dendritic cells. J. Agric. Food Chem. 2015, 63, 1730-1738. [CrossRef]

19. Regan, D.P.; Coy, J.W.; Chahal, K.K.; Chow, L.; Kurihara, J.N.; Guth, A.M.; Kufareva, I.; Dow, S.W. The Angiotensin Receptor Blocker Losartan Suppresses Growth of Pulmonary Metastases via AT1R-Independent Inhibition of CCR2 Signaling and Monocyte Recruitment. J. Immunol. 2019, 202, 3087-3102. [CrossRef]

20. Li, J.; Wang, S.; Wang, N.; Zheng, Y.; Yang, B.; Wang, X.; Zhang, J.; Pan, B.; Wang, Z. Aiduqing formula inhibits breast cancer metastasis by suppressing TAM/CXCL1-induced Treg differentiation and infiltration. Cell Commun. Signal. 2021, 19, 89. [CrossRef]

21. Frankenberger, C.; Rabe, D.; Bainer, R.; Sankarasharma, D.; Chada, K.; Krausz, T.; Gilad, Y.; Becker, L.; Rosner, M.R. Metastasis Suppressors Regulate the Tumor Microenvironment by Blocking Recruitment of Prometastatic Tumor-Associated Macrophages. Cancer Res. 2015, 75, 4063-4073. [CrossRef] [PubMed]

22. Brauß, T.F.; Winslow, S.; Lampe, S.; Scholz, A.; Weigert, A.; Dehne, N.; von Stedingk, K.; Schmid, T.; Brüne, B. The RNA-binding protein HuR inhibits expression of CCL5 and limits recruitment of macrophages into tumors. Mol. Carcinog. 2017, 56, 2620-2629. [CrossRef] [PubMed]

23. Pevida, M.; Lastra, A.; Meana, Á.; Hidalgo, A.; Baamonde, A.; Menéndez, L. The chemokine CCL5 induces CCR1-mediated hyperalgesia in mice inoculated with NCTC 2472 tumoral cells. Neuroscience 2014, 259, 113-125. [CrossRef]

24. Wani, N.; Nasser, M.W.; Ahirwar, D.K.; Zhao, H.; Miao, Z.; Shilo, K.; Ganju, R.K. C-X-C motif chemokine 12/C-X-C chemokine receptor type 7 signaling regulates breast cancer growth and metastasis by modulating the tumor microenvironment. Breast Cancer Res. 2014, 16, R54. [CrossRef] [PubMed]

25. Zhang, M.; Huang, L.; Ding, G.; Huang, H.; Cao, G.; Sun, X.; Lou, N.; Wei, Q.; Shen, T.; Xu, X.; et al. Interferon gamma inhibits CXCL8-CXCR2 axis mediated tumor-associated macrophages tumor trafficking and enhances anti-PD1 efficacy in pancreatic cancer. J. Immunother. Cancer 2020, 8, e000308. [CrossRef]

26. Lo, M.-C.; Yip, T.-C.; Ngan, K.-C.; Cheng, W.-W.; Law, C.-K.; Chan, P.-S.; Chan, K.-C.; Wong, C.K.-C.; Wong, R.N.-S.; Lo, K.-W.; et al. Role of MIF/CXCL8/CXCR2 signaling in the growth of nasopharyngeal carcinoma tumor spheres. Cancer Lett. 2013, 335, 81-92. [CrossRef] [PubMed] 
27. Cheng, R.; Billet, S.; Liu, C.; Haldar, S.; Choudhury, D.; Tripathi, M.; Hav, M.; Merchant, A.; Hu, T.; Huang, H.; et al. Periodontal inflammation recruits distant metastatic breast cancer cells by increasing myeloid-derived suppressor cells. Oncogene 2020, 39 , 1543-1556. [CrossRef]

28. Coward, J.; Kulbe, H.; Chakravarty, P.; Leader, D.; Vassileva, V.; Leinster, D.A.; Thompson, R.; Schioppa, T.; Nemeth, J.; Vermeulen, J.; et al. Interleukin-6 as a therapeutic target in human ovarian cancer. Clin. Cancer Res. 2011, 17, 6083-6096. [CrossRef]

29. Gao, H.; Zhang, I.Y.; Zhang, L.; Song, Y.; Liu, S.; Ren, H.; Liu, H.; Zhou, H.; Su, Y.; Yang, Y.; et al. S100B suppression alters polarization of infiltrating myeloid-derived cells in gliomas and inhibits tumor growth. Cancer Lett. 2018, 439, 91-100. [CrossRef]

30. Zhu, Y.; Yang, J.; Xu, D.; Gao, X.-M.; Zhang, Z.; Hsu, J.L.; Li, C.-W.; Lim, S.-O.; Sheng, Y.-Y.; Zhang, Y.; et al. Disruption of tumourassociated macrophage trafficking by the osteopontin-induced colony-stimulating factor-1 signalling sensitises hepatocellular carcinoma to anti-PD-L1 blockade. Gut 2019, 68, 1653-1666. [CrossRef]

31. Wang, J.; Wang, Y.; Chu, Y.; Li, Z.; Yu, X.; Huang, Z.; Xu, J.; Zheng, L. Tumor-derived adenosine promotes macrophage proliferation in human hepatocellular carcinoma. J. Hepatol. 2021, 74, 627-637. [CrossRef] [PubMed]

32. Baumann, D.; Drebant, J.; Hägele, T.; Burger, L.; Serger, C.; Lauenstein, C.; Dudys, P.; Erdmann, G.; Offringa, R. p38 MAPK signaling in M1 macrophages results in selective elimination of M2 macrophages by MEK inhibition. J. Immunother. Cancer 2021, 9, e002319. [CrossRef] [PubMed]

33. Tariq, M.; Zhang, J.-Q.; Liang, G.-K.; He, Q.-J.; Ding, L.; Yang, B. Gefitinib inhibits M2-like polarization of tumor-associated macrophages in Lewis lung cancer by targeting the STAT6 signaling pathway. Acta Pharm. Sin. 2017, 38, 1501-1511. [CrossRef] [PubMed]

34. Pyonteck, S.M.; Akkari, L.; Schuhmacher, A.J.; Bowman, R.L.; Sevenich, L.; Quail, D.F.; Olson, O.C.; Quick, M.L.; Huse, J.T.; Teijeiro, V.; et al. CSF-1R inhibition alters macrophage polarization and blocks glioma progression. Nat. Med. 2013, 19, 1264-1272. [CrossRef] [PubMed]

35. Huang, Y.-J.; Yang, C.-K.; Wei, P.-L.; Huynh, T.-T.; Whang-Peng, J.; Meng, T.-C.; Hsiao, M.; Tzeng, Y.-M.; Wu, A.T.; Yen, Y. Ovatodiolide suppresses colon tumorigenesis and prevents polarization of M2 tumor-associated macrophages through YAP oncogenic pathways. J. Hematol. Oncol. 2017, 10, 60. [CrossRef]

36. Zhong, Q.; Fang, Y.; Lai, Q.; Wang, S.; He, C.; Li, A.; Liu, S.; Yan, Q. CPEB3 inhibits epithelial-mesenchymal transition by disrupting the crosstalk between colorectal cancer cells and tumor-associated macrophages via IL-6R/STAT3 signaling. J. Exp. Clin. Cancer Res. 2020, 39, 132. [CrossRef]

37. Zhu, X.; Yang, J.; Gao, Y.; Wu, C.; Yi, L.; Li, G.; Qi, Y. The dual effects of a novel peptibody on angiogenesis inhibition and M2 macrophage polarization on sarcoma. Cancer Lett. 2018, 416, 1-10. [CrossRef]

38. Shu, Y.; Qin, M.; Song, Y.; Tang, Q.; Huang, Y.; Shen, P.; Lu, Y. M2 polarization of tumor-associated macrophages is dependent on integrin $\beta 3$ via peroxisome proliferator-activated receptor- $\gamma$ up-regulation in breast cancer. Immunology 2020, 160, 345-356. [CrossRef] [PubMed]

39. Lu, W.; Yu, W.; He, J.; Liu, W.; Yang, J.; Lin, X.; Zhang, Y.; Wang, X.; Jiang, W.; Luo, J.; et al. Reprogramming immunosuppressive myeloid cells facilitates immunotherapy for colorectal cancer. EMBO Mol. Med. 2021, 13, e12798. [CrossRef]

40. Jaynes, J.M.; Sable, R.; Ronzetti, M.; Bautista, W.; Knotts, Z.; Abisoye-Ogunniyan, A.; Li, D.; Calvo, R.; Dashnyam, M.; Singh, A.; et al. Mannose receptor (CD206) activation in tumor-associated macrophages enhances adaptive and innate antitumor immune responses. Sci. Transl. Med. 2020, 12, eaax6337. [CrossRef]

41. Rolny, C.; Mazzone, M.; Tugues, S.; Laoui, D.; Johansson, I.; Coulon, C.; Squadrito, M.L.; Segura, I.; Li, X.; Knevels, E.; et al. HRG inhibits tumor growth and metastasis by inducing macrophage polarization and vessel normalization through downregulation of PlGF. Cancer Cell 2011, 19, 31-44. [CrossRef] [PubMed]

42. Yang, F.; Wei, Y.; Han, D.; Li, Y.; Shi, S.; Jiao, D.; Wu, J.; Zhang, Q.; Shi, C.; Yang, L.; et al. Interaction with CD68 and Regulation of GAS6 Expression by Endosialin in Fibroblasts Drives Recruitment and Polarization of Macrophages in Hepatocellular Carcinoma. Cancer Res. 2020, 80, 3892-3905. [CrossRef] [PubMed]

43. Cohen, N.; Shani, O.; Raz, Y.; Sharon, Y.; Hoffman, D.; Abramovitz, L.; Erez, N. Fibroblasts drive an immunosuppressive and growth-promoting microenvironment in breast cancer via secretion of Chitinase 3-like 1. Oncogene 2017, 36, 4457-4468. [CrossRef] [PubMed]

44. Hawgood, S.; Akiyama, J.; Brown, C.; Allen, L.; Li, G.; Poulain, F.R. GM-CSF mediates alveolar macrophage proliferation and type II cell hypertrophy in SP-D gene-targeted mice. Am. J. Physiol. Lung Cell Mol. Physiol. 2001, 280, L1148-L1156. [CrossRef] [PubMed]

45. Wu, F.L.; Nolan, K.; Strait, A.A.; Bian, L.; Nguyen, K.A.; Wang, J.H.; Jimeno, A.; Zhou, H.M.; Young, C.D.; Wang, X.J. Macrophages Promote Growth of Squamous Cancer Independent of T cells. J. Dent. Res. 2019, 98, 896-903. [CrossRef]

46. Ferenbach, D.A.; Sheldrake, T.A.; Dhaliwal, K.; Kipari, T.M.J.; Marson, L.P.; Kluth, D.C.; Hughes, J. Macrophage/monocyte depletion by clodronate, but not diphtheria toxin, improves renal ischemia/reperfusion injury in mice. Kidney Int. 2012, 82, 928-933. [CrossRef]

47. Su, B.; Han, H.; Gong, Y.; Li, X.; Ji, C.; Yao, J.; Yang, J.; Hu, W.; Zhao, W.; Li, J.; et al. Let-7d inhibits intratumoral macrophage M2 polarization and subsequent tumor angiogenesis by targeting IL-13 and IL-10. Cancer Immunol. Immunother. 2021, 70, 1619-1634. [CrossRef] 
48. Rahal, O.M.; Wolfe, A.R.; Mandal, P.K.; Larson, R.; Tin, S.; Jimenez, C.; Zhang, D.; Horton, J.; Reuben, J.M.; McMurray, J.S.; et al. Blocking Interleukin (IL)4- and IL13-Mediated Phosphorylation of STAT6 (Tyr641) Decreases M2 Polarization of Macrophages and Protects Against Macrophage-Mediated Radioresistance of Inflammatory Breast Cancer. Int. J. Radiat. Oncol. Biol. Phys. 2018, 100, 1034-1043. [CrossRef]

49. Fu, C.; Jiang, L.; Hao, S.; Liu, Z.; Ding, S.; Zhang, W.; Yang, X.; Li, S. Activation of the IL-4/STAT6 Signaling Pathway Promotes Lung Cancer Progression by Increasing M2 Myeloid Cells. Front. Immunol. 2019, 10, 2638. [CrossRef]

50. Xue, N.; Zhou, Q.; Ji, M.; Jin, J.; Lai, F.; Chen, J.; Zhang, M.; Jia, J.; Yang, H.; Zhang, J.; et al. Chlorogenic acid inhibits glioblastoma growth through repolarizating macrophage from M2 to M1 phenotype. Sci. Rep. 2017, 7, 39011. [CrossRef]

51. Biswas, S.K.; Mantovani, A. Macrophage plasticity and interaction with lymphocyte subsets: Cancer as a paradigm. Nat. Immunol. 2010, 11, 889-896. [CrossRef] [PubMed]

52. Zhang, M.; Liu, F.; Zhou, P.; Wang, Q.; Xu, C.; Li, Y.; Bian, L.; Liu, Y.; Zhou, J.; Wang, F.; et al. The MTOR signaling pathway regulates macrophage differentiation from mouse myeloid progenitors by inhibiting autophagy. Autophagy 2019, 15, 1150-1162 [CrossRef] [PubMed]

53. Lian, G.; Chen, S.; Ouyang, M.; Li, F.; Chen, L.; Yang, J. Colon Cancer Cell Secretes EGF to Promote M2 Polarization of TAM Through EGFR/PI3K/AKT/mTOR Pathway. Technol. Cancer Res. Treat. 2019, 18, 1533033819849068. [CrossRef] [PubMed]

54. LoRusso, P.M. Inhibition of the PI3K/AKT/mTOR Pathway in Solid Tumors. J. Clin. Oncol. 2016, 34, 3803-3815. [CrossRef] [PubMed]

55. Esposito, A.; Viale, G.; Curigliano, G. Safety, Tolerability, and Management of Toxic Effects of Phosphatidylinositol 3-Kinase Inhibitor Treatment in Patients With Cancer: A Review. JAMA Oncol. 2019, 5, 1347-1354. [CrossRef] [PubMed]

56. Hu, L.; Liu, Y.; Kong, X.; Wu, R.; Peng, Q.; Zhang, Y.; Zhou, L.; Duan, L. Facilitates M2 Macrophage Polarization and Colorectal Carcinoma Progression by Activating TLR4/NF-B/S100A9 Cascade. Front. Immunol. 2021, 12, 658681. [CrossRef]

57. Kwak, T.; Wang, F.; Deng, H.; Condamine, T.; Kumar, V.; Perego, M.; Kossenkov, A.; Montaner, L.J.; Xu, X.; Xu, W.; et al. Distinct Populations of Immune-Suppressive Macrophages Differentiate from Monocytic Myeloid-Derived Suppressor Cells in Cancer. Cell Rep. 2020, 33, 108571. [CrossRef]

58. Schelbergen, R.F.; Geven, E.J.; van den Bosch, M.H.J.; Eriksson, H.; Leanderson, T.; Vogl, T.; Roth, J.; van de Loo, F.A.J.; Koenders, M.I.; van der Kraan, P.M.; et al. Prophylactic treatment with S100A9 inhibitor paquinimod reduces pathology in experimental collagenase-induced osteoarthritis. Ann. Rheum. Dis. 2015, 74, 2254-2258. [CrossRef]

59. Rodrigues, R.M.; He, Y.; Hwang, S.; Bertola, A.; Mackowiak, B.; Ahmed, Y.A.; Seo, W.; Ma, J.; Wang, X.; Park, S.H.; et al E-Selectin-Dependent Inflammation and Lipolysis in Adipose Tissue Exacerbate Steatosis-to-NASH Progression via S100A8/9. Cell Mol. Gastroenterol. Hepatol. 2021, 13, 151-171. [CrossRef]

60. Colegio, O.R.; Chu, N.-Q.; Szabo, A.L.; Chu, T.; Rhebergen, A.M.; Jairam, V.; Cyrus, N.; Brokowski, C.E.; Eisenbarth, S.C.; Phillips, G.M.; et al. Functional polarization of tumour-associated macrophages by tumour-derived lactic acid. Nature 2014, 513, 559-563. [CrossRef]

61. Chen, P.; Zuo, H.; Xiong, H.; Kolar, M.J.; Chu, Q.; Saghatelian, A.; Siegwart, D.J.; Wan, Y. Gpr132 sensing of lactate mediates tumor-macrophage interplay to promote breast cancer metastasis. Proc. Natl. Acad. Sci. USA 2017, 114, 580-585. [CrossRef] [PubMed]

62. Liu, P.-S.; Wang, H.; Li, X.; Chao, T.; Teav, T.; Christen, S.; Di Conza, G.; Cheng, W.-C.; Chou, C.-H.; Vavakova, M.; et al. $\alpha$-ketoglutarate orchestrates macrophage activation through metabolic and epigenetic reprogramming. Nat. Immunol. 2017, 18, 985-994. [CrossRef] [PubMed]

63. Tannahill, G.M.; Curtis, A.M.; Adamik, J.; Palsson-McDermott, E.M.; McGettrick, A.F.; Goel, G.; Frezza, C.; Bernard, N.J.; Kelly, B.; Foley, N.H.; et al. Succinate is an inflammatory signal that induces IL-1 $\beta$ through HIF-1 $\alpha$. Nature 2013, 496, 238-242. [CrossRef] [PubMed]

64. Mehla, K.; Singh, P.K. Metabolic Regulation of Macrophage Polarization in Cancer. Trends Cancer 2019, 5, 822-834. [CrossRef]

65. Odegaard, J.I.; Ricardo-Gonzalez, R.R.; Goforth, M.H.; Morel, C.R.; Subramanian, V.; Mukundan, L.; Red Eagle, A.; Vats, D.; Brombacher, F.; Ferrante, A.W.; et al. Macrophage-specific PPARgamma controls alternative activation and improves insulin resistance. Nature 2007, 447, 1116-1120. [CrossRef]

66. Vats, D.; Mukundan, L.; Odegaard, J.I.; Zhang, L.; Smith, K.L.; Morel, C.R.; Wagner, R.A.; Greaves, D.R.; Murray, P.J.; Chawla, A. Oxidative metabolism and PGC-1beta attenuate macrophage-mediated inflammation. Cell Metab. 2006, 4, 13-24. [CrossRef]

67. Niu, Z.; Shi, Q.; Zhang, W.; Shu, Y.; Yang, N.; Chen, B.; Wang, Q.; Zhao, X.; Chen, J.; Cheng, N.; et al. Caspase-1 cleaves PPAR $\gamma$ for potentiating the pro-tumor action of TAMs. Nat. Commun. 2017, 8, 766. [CrossRef] [PubMed]

68. Wu, L.; Zhang, X.; Zheng, L.; Zhao, H.; Yan, G.; Zhang, Q.; Zhou, Y.; Lei, J.; Zhang, J.; Wang, J.; et al. RIPK3 Orchestrates Fatty Acid Metabolism in Tumor-Associated Macrophages and Hepatocarcinogenesis. Cancer Immunol. Res. 2020, 8, 710-721. [CrossRef]

69. Lankadasari, M.B.; Mukhopadhyay, P.; Mohammed, S.; Harikumar, K.B. TAMing pancreatic cancer: Combat with a double edged sword. Mol. Cancer 2019, 18, 48. [CrossRef] [PubMed]

70. Penny, H.L.; Sieow, J.L.; Adriani, G.; Yeap, W.H.; See Chi Ee, P.; San Luis, B.; Lee, B.; Lee, T.; Mak, S.Y.; Ho, Y.S.; et al Warburg metabolism in tumor-conditioned macrophages promotes metastasis in human pancreatic ductal adenocarcinoma. Oncoimmunology 2016, 5, e1191731. [CrossRef]

71. Wei, Z.; Zhang, X.; Yong, T.; Bie, N.; Zhan, G.; Li, X.; Liang, Q.; Li, J.; Yu, J.; Huang, G.; et al. Boosting anti-PD-1 therapy with metformin-loaded macrophage-derived microparticles. Nat. Commun. 2021, 12, 440. [CrossRef] [PubMed] 
72. Qian, B.-Z.; Pollard, J.W. Macrophage diversity enhances tumor progression and metastasis. Cell 2010, 141, 39-51. [CrossRef] [PubMed]

73. Noy, R.; Pollard, J.W. Tumor-associated macrophages: From mechanisms to therapy. Immunity 2014, 41, 49-61. [CrossRef] [PubMed]

74. Zhang, Y.; Yu, G.; Chu, H.; Wang, X.; Xiong, L.; Cai, G.; Liu, R.; Gao, H.; Tao, B.; Li, W.; et al. Macrophage-Associated PGK1 Phosphorylation Promotes Aerobic Glycolysis and Tumorigenesis. Mol. Cell 2018, 71, 201-215. [CrossRef] [PubMed]

75. Mano, Y.; Aishima, S.; Fujita, N.; Tanaka, Y.; Kubo, Y.; Motomura, T.; Taketomi, A.; Shirabe, K.; Maehara, Y.; Oda, Y. Tumorassociated macrophage promotes tumor progression via STAT3 signaling in hepatocellular carcinoma. Pathobiology 2013, 80, 146-154. [CrossRef] [PubMed]

76. Kesanakurti, D.; Chetty, C.; Dinh, D.H.; Gujrati, M.; Rao, J.S. Role of MMP-2 in the regulation of IL-6/Stat3 survival signaling via interaction with $\alpha 5 \beta 1$ integrin in glioma. Oncogene 2013, 32, 327-340. [CrossRef]

77. Yuan, H.; Lin, Z.; Liu, Y.; Jiang, Y.; Liu, K.; Tu, M.; Yao, N.; Qu, C.; Hong, J. Intrahepatic cholangiocarcinoma induced M2-polarized tumor-associated macrophages facilitate tumor growth and invasiveness. Cancer Cell Int. 2020, 20, 586. [CrossRef] [PubMed]

78. Wang, Y.; Lyu, Z.; Qin, Y.; Wang, X.; Sun, L.; Zhang, Y.; Gong, L.; Wu, S.; Han, S.; Tang, Y.; et al. FOXO1 promotes tumor progression by increased M2 macrophage infiltration in esophageal squamous cell carcinoma. Theranostics 2020, 10, 11535-11548 [CrossRef]

79. Wang, L.; Wang, Y.-X.; Zhang, D.-Z.; Fang, X.-J.; Sun, P.-S.; Xue, H.-C. Let-7a mimic attenuates CCL18 induced breast cancer cell metastasis through Lin 28 pathway. Biomed. Pharm. 2016, 78, 301-307. [CrossRef]

80. Günther, C.; Zimmermann, N.; Berndt, N.; Grosser, M.; Stein, A.; Koch, A.; Meurer, M. Up-regulation of the chemokine CCL18 by macrophages is a potential immunomodulatory pathway in cutaneous T-cell lymphoma. Am. J. Pathol. 2011, 179, 1434-1442. [CrossRef]

81. Liu, C.; Zhang, W.; Wang, J.; Si, T.; Xing, W. Tumor-associated macrophage-derived transforming growth factor- $\beta$ promotes colorectal cancer progression through HIF1-TRIB3 signaling. Cancer Sci. 2021, 112, 4198-4207. [CrossRef] [PubMed]

82. Fan, Q.-M.; Jing, Y.-Y.; Yu, G.-F.; Kou, X.-R.; Ye, F.; Gao, L.; Li, R.; Zhao, Q.-D.; Yang, Y.; Lu, Z.-H.; et al. Tumor-associated macrophages promote cancer stem cell-like properties via transforming growth factor-beta1-induced epithelial-mesenchymal transition in hepatocellular carcinoma. Cancer Lett. 2014, 352, 160-168. [CrossRef] [PubMed]

83. Okamoto, M.; Koma, Y.-I.; Kodama, T.; Nishio, M.; Shigeoka, M.; Yokozaki, H. Growth Differentiation Factor 15 Promotes Progression of Esophageal Squamous Cell Carcinoma via TGF- $\beta$ Type II Receptor Activation. Pathobiology 2020, 87, 100-113. [CrossRef] [PubMed]

84. Hagemann, T.; Wilson, J.; Kulbe, H.; Li, N.F.; Leinster, D.A.; Charles, K.; Klemm, F.; Pukrop, T.; Binder, C.; Balkwill, F.R. Macrophages induce invasiveness of epithelial cancer cells via NF-kappa B and JNK. J. Immunol. 2005, 175, 1197-1205. [CrossRef] [PubMed]

85. Cho, U.; Kim, B.; Kim, S.; Han, Y.; Song, Y.S. Pro-inflammatory M1 macrophage enhances metastatic potential of ovarian cancer cells through NF-кB activation. Mol. Carcinog. 2018, 57, 235-242. [CrossRef]

86. Singh, R.; Shankar, B.S.; Sainis, K.B. TGF- $31-R O S-A T M-C R E B$ signaling axis in macrophage mediated migration of human breast cancer MCF7 cells. Cell Signal. 2014, 26, 1604-1615. [CrossRef]

87. Watanabe, H.; Iwase, M.; Ohashi, M.; Nagumo, M. Role of interleukin-8 secreted from human oral squamous cell carcinoma cell lines. Oral Oncol. 2002, 38, 670-679. [CrossRef]

88. Pang, L.; Han, S.; Jiao, Y.; Jiang, S.; He, X.; Li, P. Bu Fei Decoction attenuates the tumor associated macrophage stimulated proliferation, migration, invasion and immunosuppression of non-small cell lung cancer, partially via IL-10 and PD-L1 regulation. Int. J. Oncol. 2017, 51, 25-38. [CrossRef]

89. Lee, J.-H.; Lee, G.T.; Woo, S.H.; Ha, Y.-S.; Kwon, S.J.; Kim, W.-J.; Kim, I.Y. BMP-6 in renal cell carcinoma promotes tumor proliferation through IL-10-dependent M2 polarization of tumor-associated macrophages. Cancer Res. 2013, 73, 3604-3614 [CrossRef]

90. Choi, S.; Kim, H.-R.; Leng, L.; Kang, I.; Jorgensen, W.L.; Cho, C.-S.; Bucala, R.; Kim, W.-U. Role of macrophage migration inhibitory factor in the regulatory $\mathrm{T}$ cell response of tumor-bearing mice. J. Immunol. 2012, 189, 3905-3913. [CrossRef]

91. Chen, X.; Gao, A.; Zhang, F.; Yang, Z.; Wang, S.; Fang, Y.; Li, J.; Wang, J.; Shi, W.; Wang, L.; et al. ILT4 inhibition prevents TAMand dysfunctional T cell-mediated immunosuppression and enhances the efficacy of anti-PD-L1 therapy in NSCLC with EGFR activation. Theranostics 2021, 11, 3392-3416. [CrossRef] [PubMed]

92. Phinney, B.B.; Ray, A.L.; Peretti, A.S.; Jerman, S.J.; Grim, C.; Pinchuk, I.V.; Beswick, E.J. MK2 Regulates Macrophage Chemokine Activity and Recruitment to Promote Colon Tumor Growth. Front. Immunol. 2018, 9, 1857. [CrossRef] [PubMed]

93. Liu, Y.; Song, C.; Shen, F.; Zhang, J.; Song, S.W. IGFBP2 promotes immunosuppression associated with its mesenchymal induction and Fc $\gamma$ RIIB phosphorylation in glioblastoma. PLoS ONE 2019, 14, e0222999. [CrossRef] [PubMed]

94. Lim, S.Y.; Yuzhalin, A.E.; Gordon-Weeks, A.N.; Muschel, R.J. Tumor-infiltrating monocytes/macrophages promote tumor invasion and migration by upregulating S100A8 and S100A9 expression in cancer cells. Oncogene 2016, 35, 5735-5745. [CrossRef]

95. Palmieri, E.M.; Menga, A.; Martín-Pérez, R.; Quinto, A.; Riera-Domingo, C.; De Tullio, G.; Hooper, D.C.; Lamers, W.H.; Ghesquière, B.; McVicar, D.W.; et al. Pharmacologic or Genetic Targeting of Glutamine Synthetase Skews Macrophages toward an M1-like Phenotype and Inhibits Tumor Metastasis. Cell Rep. 2017, 20, 1654-1666. [CrossRef] 
96. Lu, Z.; Zheng, S.; Liu, C.; Wang, X.; Zhang, G.; Wang, F.; Wang, S.; Huang, J.; Mao, S.; Lei, Y.; et al. S100A7 as a potential diagnostic and prognostic biomarker of esophageal squamous cell carcinoma promotes M2 macrophage infiltration and angiogenesis. Clin. Transl. Med. 2021, 11, e459. [CrossRef]

97. Yang, J.; Pi, C.; Wang, G. Inhibition of PI3K/Akt/mTOR pathway by apigenin induces apoptosis and autophagy in hepatocellular carcinoma cells. Biomed. Pharm. 2018, 103, 699-707. [CrossRef]

98. Weichand, B.; Popp, R.; Dziumbla, S.; Mora, J.; Strack, E.; Elwakeel, E.; Frank, A.-C.; Scholich, K.; Pierre, S.; Syed, S.N.; et al. S1PR1 on tumor-associated macrophages promotes lymphangiogenesis and metastasis via NLRP3/IL-1ß. J. Exp. Med. 2017, 214, 2695-2713. [CrossRef]

99. Chen, P.; Zhao, D.; Li, J.; Liang, X.; Li, J.; Chang, A.; Henry, V.K.; Lan, Z.; Spring, D.J.; Rao, G.; et al. Symbiotic Macrophage-Glioma Cell Interactions Reveal Synthetic Lethality in PTEN-Null Glioma. Cancer Cell 2019, 35, 868-884. [CrossRef]

100. Liu, D.; Lu, Q.; Wang, X.; Wang, J.; Lu, N.; Jiang, Z.; Hao, X.; Li, J.; Liu, J.; Cao, P.; et al. LSECtin on tumor-associated macrophages enhances breast cancer stemness via interaction with its receptor BTN3A3. Cell Res. 2019, 29, 365-378. [CrossRef]

101. Zhang, X.; Chen, L.; Dang, W.-Q.; Cao, M.-F.; Xiao, J.-F.; Lv, S.-Q.; Jiang, W.-J.; Yao, X.-H.; Lu, H.-M.; Miao, J.-Y.; et al. CCL8 secreted by tumor-associated macrophages promotes invasion and stemness of glioblastoma cells via ERK1/2 signaling. Lab. Investig. 2020, 100, 619-629. [CrossRef] [PubMed]

102. Ning, Y.; Cui, Y.; Li, X.; Cao, X.; Chen, A.; Xu, C.; Cao, J.; Luo, X. Co-culture of ovarian cancer stem-like cells with macrophages induced SKOV3 cells stemness via IL-8/STAT3 signaling. Biomed. Pharm. 2018, 103, 262-271. [CrossRef] [PubMed]

103. Zhang, Y.; Kang, M.; Zhang, B.; Meng, F.; Song, J.; Kaneko, H.; Shimamoto, F.; Tang, B. mA modification-mediated CBX8 induction regulates stemness and chemosensitivity of colon cancer via upregulation of LGR5. Mol. Cancer 2019, 18, 185. [CrossRef] [PubMed]

104. Joshi, S.; Singh, A.R.; Zulcic, M.; Durden, D.L. A macrophage-dominant PI3K isoform controls hypoxia-induced HIF1 $\alpha$ and HIF2 $\alpha$ stability and tumor growth, angiogenesis, and metastasis. Mol. Cancer Res. 2014, 12, 1520-1531. [CrossRef] [PubMed]

105. Dong, F.; Ruan, S.; Wang, J.; Xia, Y.; Le, K.; Xiao, X.; Hu, T.; Wang, Q. M2 macrophage-induced lncRNA PCAT6 facilitates tumorigenesis and angiogenesis of triple-negative breast cancer through modulation of VEGFR2. Cell Death Dis. 2020, 11, 728. [CrossRef] [PubMed]

106. Ellis, L.M.; Hicklin, D.J. VEGF-targeted therapy: Mechanisms of anti-tumour activity. Nat. Rev. Cancer 2008, 8, 579-591. [CrossRef] [PubMed]

107. Narang, A.S.; Varia, S. Role of tumor vascular architecture in drug delivery. Adv. Drug Deliv. Rev. 2011, 63, 640-658. [CrossRef] [PubMed]

108. Konerding, M.A.; Malkusch, W.; Klapthor, B.; van Ackeern, C.; Fait, E.; Hill, S.A.; Parkins, C.; Chaplin, D.J.; Presta, M.; Denekamp, J. Evidence for characteristic vascular patterns in solid tumours: Quantitative studies using corrosion casts. Br. J. Cancer 1999, 80, 724-732. [CrossRef]

109. Dvorak, H.F.; Nagy, J.A.; Dvorak, J.T.; Dvorak, A.M. Identification and characterization of the blood vessels of solid tumors that are leaky to circulating macromolecules. Am. J. Pathol. 1988, 133, 95.

110. Eberhard, A.; Kahlert, S.; Goede, V.; Hemmerlein, B.; Plate, K.H.; Augustin, H.G. Heterogeneity of angiogenesis and blood vessel maturation in human tumors: Implications for antiangiogenic tumor therapies. Cancer Res. 2000, 60, 1388-1393. [PubMed]

111. Paku, S.; Paweletz, N. First steps of tumor-related angiogenesis. Lab. Investig. 1991, 65, 334-346. [PubMed]

112. Wenes, M.; Shang, M.; Di Matteo, M.; Goveia, J.; Martín-Pérez, R.; Serneels, J.; Prenen, H.; Ghesquière, B.; Carmeliet, P.; Mazzone, M. Macrophage Metabolism Controls Tumor Blood Vessel Morphogenesis and Metastasis. Cell Metab. 2016, 24, 701-715. [CrossRef] [PubMed]

113. Chen, W.; Ma, T.; Shen, X.-N.; Xia, X.-F.; Xu, G.-D.; Bai, X.-L.; Liang, T.-B. Macrophage-induced tumor angiogenesis is regulated by the TSC2-mTOR pathway. Cancer Res. 2012, 72, 1363-1372. [CrossRef] [PubMed]

114. Liu, L.; Tao, T.; Liu, S.; Yang, X.; Chen, X.; Liang, J.; Hong, R.; Wang, W.; Yang, Y.; Li, X.; et al. An RFC4/Notch1 signaling feedback loop promotes NSCLC metastasis and stemness. Nat. Commun. 2021, 12, 2693. [CrossRef]

115. Allavena, P.; Anfray, C.; Ummarino, A.; Andón, F.T. Therapeutic Manipulation of Tumor-associated Macrophages: Facts and Hopes from a Clinical and Translational Perspective. Clin. Cancer Res. 2021, 27, 3291-3297. [CrossRef]

116. Liguori, M.; Digifico, E.; Vacchini, A.; Avigni, R.; Colombo, F.S.; Borroni, E.M.; Farina, F.M.; Milanesi, S.; Castagna, A.; Mannarino, L.; et al. The soluble glycoprotein NMB (GPNMB) produced by macrophages induces cancer stemness and metastasis via CD44 and IL-33. Cell Mol. Immunol. 2021, 18, 711-722. [CrossRef]

117. Maric, G.; Annis, M.G.; MacDonald, P.A.; Russo, C.; Perkins, D.; Siwak, D.R.; Mills, G.B.; Siegel, P.M. GPNMB augments Wnt-1 mediated breast tumor initiation and growth by enhancing PI3K/AKT/mTOR pathway signaling and $\beta$-catenin activity. Oncogene 2019, 38, 5294-5307. [CrossRef]

118. Gomez, K.E.; Wu, F.; Keysar, S.B.; Morton, J.J.; Miller, B.; Chimed, T.-S.; Le, P.N.; Nieto, C.; Chowdhury, F.N.; Tyagi, A.; et al. Cancer Cell CD44 Mediates Macrophage/Monocyte-Driven Regulation of Head and Neck Cancer Stem Cells. Cancer Res. 2020, 80, 4185-4198. [CrossRef]

119. Sohn, S.-H.; Kim, B.; Sul, H.J.; Choi, B.Y.; Kim, H.S.; Zang, D.Y. Foretinib Inhibits Cancer Stemness and Gastric Cancer Cell Proliferation by Decreasing CD44 and c-MET Signaling. Onco Targets 2020, 13, 1027-1035. [CrossRef] 
120. Li, D.; Ji, H.; Niu, X.; Yin, L.; Wang, Y.; Gu, Y.; Wang, J.; Zhou, X.; Zhang, H.; Zhang, Q. Tumor-associated macrophages secrete CC-chemokine ligand 2 and induce tamoxifen resistance by activating PI3K/Akt/mTOR in breast cancer. Cancer Sci. 2020, 111, 47-58. [CrossRef]

121. Quail, D.F.; Bowman, R.L.; Akkari, L.; Quick, M.L.; Schuhmacher, A.J.; Huse, J.T.; Holland, E.C.; Sutton, J.C.; Joyce, J.A. The tumor microenvironment underlies acquired resistance to CSF-1R inhibition in gliomas. Science 2016, 352, aad3018. [CrossRef] [PubMed]

122. Liu, Y.; Ji, X.; Kang, N.; Zhou, J.; Liang, X.; Li, J.; Han, T.; Zhao, C.; Yang, T. Tumor necrosis factor $\alpha$ inhibition overcomes immunosuppressive M2b macrophage-induced bevacizumab resistance in triple-negative breast cancer. Cell Death Dis. 2020, 11, 993. [CrossRef] [PubMed]

123. Zhang, Q.; Wang, H.; Mao, C.; Sun, M.; Dominah, G.; Chen, L.; Zhuang, Z. Fatty acid oxidation contributes to IL-1 $\beta$ secretion in M2 macrophages and promotes macro.ophage-medi.iated tumor cell migration. Mol. Immunol. 2018, 94, 27-35. [CrossRef] [PubMed]

124. Wei, C.; Yang, C.; Wang, S.; Shi, D.; Zhang, C.; Lin, X.; Liu, Q.; Dou, R.; Xiong, B. Crosstalk between cancer cells and tumor associated macrophages is required for mesenchymal circulating tumor cell-mediated colorectal cancer metastasis. Mol. Cancer 2019, 18, 64. [CrossRef]

125. Gao, S.; Hu, J.; Wu, X.; Liang, Z. PMA treated THP-1-derived-IL-6 promotes EMT of SW48 through STAT3/ERK-dependent activation of Wnt/ $\beta$-catenin signaling pathway. Biomed. Pharm. 2018, 108, 618-624. [CrossRef]

126. Ham, S.; Lima, L.G.; Chai, E.P.Z.; Muller, A.; Lobb, R.J.; Krumeich, S.; Wen, S.W.; Wiegmans, A.P.; Möller, A. Breast Cancer-Derived Exosomes Alter Macrophage Polarization gp130/STAT3 Signaling. Front. Immunol. 2018, 9, 871. [CrossRef]

127. Jiang, J.; Wang, G.-Z.; Wang, Y.; Huang, H.-Z.; Li, W.-T.; Qu, X.-D. Hypoxia-induced HMGB1 expression of HCC promotes tumor invasiveness and metastasis via regulating macrophage-derived IL-6. Exp. Cell Res. 2018, 367, 81-88. [CrossRef]

128. Liu, C.-Y.; Xu, J.-Y.; Shi, X.-Y.; Huang, W.; Ruan, T.-Y.; Xie, P.; Ding, J.-L. M2-polarized tumor-associated macrophages promoted epithelial-mesenchymal transition in pancreatic.c cancer cells, partially through TLR4/IL-10 signaling pathway. Lab. Investig. 2013, 93, 844-854. [CrossRef]

129. Ruffell, B.; Chang-Strachan, D.; Chan, V.; Rosenbusch, A.; Ho, C.M.T.; Pryer, N.; Daniel, D.; Hwang, E.S.; Rugo, H.S.; Coussens, L.M. Macrophage IL-10 blocks CD8+ T cell-dependent responses to chemotherapy by suppressing IL-12 expression in intratumoral dendritic cells. Cancer Cell 2014, 26, 623-637. [CrossRef]

130. Fu, Q.; Xu, L.; Wang, Y.; Jiang, Q.; Liu, Z.; Zhang, J.; Zhou, Q.; Zeng, H.; Tong, S.; Wang, T.; et al. Tumor-associated Macrophagederived Interleukin-23 Interlinks Kidney Cancer Glutamine Addiction with Immune Evasion. Eur. Urol. 2019, 75, 752-763. [CrossRef]

131. Nie, W.; Yu, T.; Sang, Y.; Gao, X. Tumor-promoting effect of IL-23 in mammary cancer mediated by infiltration of M2 macrophages and neutrophils in tumor microenvironment. Biochem. Biophys. Res. Commun. 2017, 482, 1400-1406. [CrossRef] [PubMed]

132. Franzè, E.; Laudisi, F.; Di Grazia, A.; Marônek, M.; Bellato, V.; Sica, G.; Monteleone, G. Macrophages produce and functionally respond to interleukin-34 in colon cancer. Cell Death Discov. 2020, 6, 117. [CrossRef]

133. Liu, C.; Yao, Z.; Wang, J.; Zhang, W.; Yang, Y.; Zhang, Y.; Qu, X.; Zhu, Y.; Zou, J.; Peng, S.; et al. Macrophage-derived CCL5 facilitates immune escape of colorectal cancer cells via the p65/STAT3-CSN5-PD-L1 pathway. Cell Death Differ. 2020, 27, 1765-1781. [CrossRef] [PubMed]

134. Suarez-Lopez, L.; Kong, Y.W.; Sriram, G.; Patterson, J.C.; Rosenberg, S.; Morandell, S.; Haigis, K.M.; Yaffe, M.B. MAPKAP Kinase-2 Drives Expression of Angiogenic Factors by Tumor-Associated Macrophages in a Model of Inflammation-Induced Colon Cancer. Front. Immunol. 2020, 11, 607891. [CrossRef] [PubMed]

135. Zhao, C.; Zheng, S.; Yan, Z.; Deng, Z.; Wang, R.; Zhang, B. CCL18 promotes the invasion and metastasis of breast cancer through Annexin A2. Oncol. Rep. 2020, 43, 571-580. [CrossRef]

136. Pham, T.-H.; Bak, Y.; Kwon, T.; Kwon, S.-B.; Oh, J.-W.; Park, J.-H.; Choi, Y.-K.; Hong, J.T.; Yoon, D.-Y. Interleukin-320 inhibits tumor-promoting effects of macrophage-secreted CCL18 in breast cancer. Cell Commun. Signal. 2019, 17, 53. [CrossRef]

137. Liu, J.; Zhang, N.; Li, Q.; Zhang, W.; Ke, F.; Leng, Q.; Wang, H.; Chen, J.; Wang, H. Tumor-associated macrophages recruit CCR6 ${ }^{+}$regulatory T cells and promote the development of colorectal cancer via enhancing CCL20 production in mice. PLoS ONE 2011, 6, e19495. [CrossRef]

138. Wang, D.; Yang, L.; Yue, D.; Cao, L.; Li, L.; Wang, D.; Ping, Y.; Shen, Z.; Zheng, Y.; Wang, L.; et al. Macrophage-derived CCL22 promotes an immunosuppressive tumor microenvironment via IL-8 in malignant pleural effusion. Cancer Lett. 2019, 452, 244-253. [CrossRef]

139. Zhao, P.; Wang, B.; Zhang, Z.; Zhang, W.; Liu, Y. Response gene to complement 32 expression in macrophages augments paracrine stimulation-mediated colon cancer progression. Cell Death Dis. 2019, 10, 776. [CrossRef]

140. Wang, D.; Wang, R.; Huang, A.; Fang, Z.; Wang, K.; He, M.; Xia, J.-T.; Li, W. Upregulation of macrophage migration inhibitory factor promotes tumor metastasis and correlates with poor prognosis of pancreatic ductal adenocarcinoma. Oncol. Rep. 2018, 40, 2628-2636. [CrossRef]

141. Zhao, Y.; Yu, Z.; Ma, R.; Zhang, Y.; Zhao, L.; Yan, Y.; Lv, X.; Zhang, L.; Su, P.; Bi, J.; et al. lncRNA-Xist/miR-101-3p/KLF6/C/EBP $\alpha$ axis promotes TAM polarization to regulate cancer cell proliferation and migration. Mol. Nucleic Acids 2021, 23, 536-551. [CrossRef] [PubMed]

142. Luput, L.; Licarete, E.; Sesarman, A.; Patras, L.; Alupei, M.C.; Banciu, M. Tumor-associated macrophages favor C26 murine colon carcinoma cell proliferation in a.an oxidative stress-dependent manner. Oncol. Rep. 2017, 37, 2472-2480. [CrossRef] [PubMed] 
143. Kwon, S.J.; Lee, G.T.; Lee, J.-H.; Iwakura, Y.; Kim, W.-J.; Kim, I.Y. Mechanism of pro-tumorigenic effect of BMP-6: Neovascularization involving tumor-associated macrophages and IL-1a. Prostate 2014, 74, 121-133. [CrossRef] [PubMed]

144. Pagano, E.; Elias, J.E.; Schneditz, G.; Saveljeva, S.; Holland, L.M.; Borrelli, F.; Karlsen, T.H.; Kaser, A.; Kaneider, N.C. Activation of the GPR35 pathway drives angiogenesis in the tumour microenvironment. Gut 2021, 71, 509-520. [CrossRef]

145. Schuette, V.; Embgenbroich, M.; Ulas, T.; Welz, M.; Schulte-Schrepping, J.; Draffehn, A.M.; Quast, T.; Koch, K.; Nehring, M.; König, J.; et al. Mannose receptor induces T-cell tolerance via inhibition of CD45 and up-regulation of CTLA-4. Proc. Natl. Acad. Sci. USA 2016, 113, 10649-10654. [CrossRef] [PubMed]

146. Lu, C.-S.; Shiau, A.-L.; Su, B.-H.; Hsu, T.-S.; Wang, C.-T.; Su, Y.-C.; Tsai, M.-S.; Feng, Y.-H.; Tseng, Y.-L.; Yen, Y.-T.; et al Oct4 promotes M2 macrophage polarization through upregulation of macrophage colony-stimulating factor in lung cancer. J. Hematol. Oncol. 2020, 13, 62. [CrossRef]

147. Chen, Y.; Zhang, S.; Wang, Q.; Zhang, X. Tumor-recruited M2 macrophages promote gastric and breast cancer metastasis via M2 macrophage-secreted CHI3L1 protein. J. Hematol. Oncol. 2017, 10, 36. [CrossRef]

148. Dan, H.; Liu, S.; Liu, J.; Liu, D.; Yin, F.; Wei, Z.; Wang, J.; Zhou, Y.; Jiang, L.; Ji, N.; et al. RACK1 promotes cancer progression by increasing the M2/M1 macrophage ratio via the NF- KB pathway in oral squamous cell carcinoma. Mol. Oncol. 2020, 14, 795-807. [CrossRef]

149. Wei, R.; Zhu, W.-W.; Yu, G.-Y.; Wang, X.; Gao, C.; Zhou, X.; Lin, Z.-F.; Shao, W.-Q.; Wang, S.-H.; Lu, M.; et al. S100 calcium-binding protein A9 from tumor-associated macrophage enhances cancer stem cell-like properties of hepatocellular carcinoma. Int. J. Cancer 2021, 148, 1233-1244. [CrossRef]

150. Kerkar, S.P.; Restifo, N.P. Cellular constituents of immune escape within the tumor microenvironment. Cancer Res. 2012, 72 , 3125-3130. [CrossRef]

151. Luo, Y.; Zhou, H.; Krueger, J.; Kaplan, C.; Lee, S.-H.; Dolman, C.; Markowitz, D.; Wu, W.; Liu, C.; Reisfeld, R.A.; et al. Targeting tumor-associated macrophages as a novel strategy against breast cancer. J. Clin. Investig. 2006, 116, 2132-2141. [CrossRef]

152. Miller, M.R.; Mandell, J.B.; Beatty, K.M.; Harvey, S.A.K.; Rizzo, M.J.; Previte, D.M.; Thorne, S.H.; McKenna, K.C. Splenectomy promotes indirect elimination of intraocular tumors by CD8 ${ }^{+} \mathrm{T}$ cells that is associated with IFN $\gamma$ - and Fas/FasL-dependent activation of intratumoral macrophages. Cancer Immunol. Res. 2014, 2, 1175-1185. [CrossRef] [PubMed]

153. Yu, J.; Green, M.D.; Li, S.; Sun, Y.; Journey, S.N.; Choi, J.E.; Rizvi, S.M.; Qin, A.; Waninger, J.J.; Lang, X.; et al. Liver metastasis restrains immunotherapy efficacy via macrophage-mediated T cell elimination. Nat. Med. 2021, 27, 152-164. [CrossRef]

154. Rodriguez, P.C.; Ruffell, B. Cavity macrophages stop anti-tumor T cells. Cancer Cell 2021, 39, 900-902. [CrossRef]

155. Xia, H.; Li, S.; Li, X.; Wang, W.; Bian, Y.; Wei, S.; Grove, S.; Wang, W.; Vatan, L.; Liu, J.R.; et al. Autophagic adaptation to oxidative stress alters peritoneal residential macrophage survival and ovarian cancer metastasis. JCI Insight 2020, 5, e141115. [CrossRef]

156. McGrath, M.M. Diverse roles of TIM4 in immune activation: Implications for alloimmunity. Curr. Opin. Organ Transpl. 2018, 23, 44-50. [CrossRef] [PubMed]

157. Miyanishi, M.; Tada, K.; Koike, M.; Uchiyama, Y.; Kitamura, T.; Nagata, S. Identification of Tim4 as a phosphatidylserine receptor. Nature 2007, 450, 435-439. [CrossRef] [PubMed]

158. La Fleur, L.; Botling, J.; He, F.; Pelicano, C.; Zhou, C.; He, C.; Palano, G.; Mezheyeuski, A.; Micke, P.; Ravetch, J.V.; et al. Targeting MARCO and IL37R on Immunosuppressive Macrophages in Lung Cancer Blocks Regulatory T Cells and Supports Cytotoxic Lymphocyte Function. Cancer Res. 2021, 81, 956-967. [CrossRef]

159. Gyori, D.; Lim, E.L.; Grant, F.M.; Spensberger, D.; Roychoudhuri, R.; Shuttleworth, S.J.; Okkenhaug, K.; Stephens, L.R.; Hawkins, P.T. Compensation between CSF1 $\mathrm{R}^{+}$macrophages and Foxp3+ Treg cells drives resistance to tumor immunotherapy. JCI Insight 2018, 3, e120631. [CrossRef]

160. Liu, C.; Chikina, M.; Deshpande, R.; Menk, A.V.; Wang, T.; Tabib, T.; Brunazzi, E.A.; Vignali, K.M.; Sun, M.; Stolz, D.B.; et al. Treg Cells Promote the SREBP1-Dependent Metabolic Fitness of Tumor-Promoting Macrophages via Repression of CD8 T Cell-Derived Interferon- $\gamma$. Immunity 2019, 51, 381-397. [CrossRef]

161. Rothlin, C.V.; Carrera-Silva, E.A.; Bosurgi, L.; Ghosh, S. TAM receptor signaling in immune homeostasis. Annu. Rev. Immunol. 2015, 33, 355-391. [CrossRef] [PubMed]

162. offe, A.M.; Bakalar, M.H.; Fletcher, D.A. Macrophage phagocytosis assay with reconstituted target particles. Nat. Protoc. 2020, 15, 2230-2246. [CrossRef]

163. Majeti, R.; Chao, M.P.; Alizadeh, A.A.; Pang, W.W.; Jaiswal, S.; Gibbs, K.D.; van Rooijen, N.; Weissman, I.L. CD47 is an adverse prognostic factor and therapeutic antibody.....y target on human acute myeloid leukemia stem cells. Cell 2009, 138, 286-299. [CrossRef] [PubMed]

164. Willingham, S.B.; Volkmer, J.-P.; Gentles, A.J.; Sahoo, D.; Dalerba, P.; Mitra, S.S.; Wang, J.; Contreras-Trujillo, H.; Martin, R.; Cohen, J.D.; et al. The CD47-signal regulatory protein alpha (SIRPa) interaction is a therapeutic target for human solid tumors. Proc. Natl. Acad. Sci. USA 2012, 109, 6662-6667. [CrossRef] [PubMed]

165. Feng, M.; Jiang, W.; Kim, B.Y.S.; Zhang, C.C.; Fu, Y.-X.; Weissman, I.L. Phagocytosis checkpoints as new targets for cancer immunotherapy. Nat. Rev. Cancer 2019, 19, 568-586. [CrossRef]

166. Advani, R.; Flinn, I.; Popplewell, L.; Forero, A.; Bartlett, N.L.; Ghosh, N.; Kline, J.; Roschewski, M.; LaCasce, A.; Collins, G.P.; et al CD47 Blockade by Hu5F9-G4 and Rituximab in Non-Hodgkin's Lymphoma. N. Engl. J. Med. 2018, 379, 1711-1721. [CrossRef]

167. Ye, T.; Liu, J.; Zhao, W.; Gao, S.; Wang, S.; Wu, F.; Zhou, H. The hypothesis of tumor-associated macrophages mediating semi-phagocytosis of cancer cells in distant metastasis. Future Oncol. 2021, 17, 1125-1129. [CrossRef] 
168. Gordon, S.R.; Maute, R.L.; Dulken, B.W.; Hutter, G.; George, B.M.; McCracken, M.N.; Gupta, R.; Tsai, J.M.; Sinha, R.; Corey, D.; et al. PD-1 expression by tumour-associated macrophages inhibits phagocytosis and tumour immunity. Nature 2017, 545, 495-499. [CrossRef]

169. Barkal, A.A.; Weiskopf, K.; Kao, K.S.; Gordon, S.R.; Rosental, B.; Yiu, Y.Y.; George, B.M.; Markovic, M.; Ring, N.G.; Tsai, J.M.; et al. Engagement of MHC class I by the inhibitory receptor LILRB1 suppresses macrophages and is a target of cancer immunotherapy. Nat. Immunol. 2018, 19, 76-84. [CrossRef]

170. Zhao, J.; Zhong, S.; Niu, X.; Jiang, J.; Zhang, R.; Li, Q. The MHC class I-LILRB1 signalling axis as a promising target in cancer therapy. Scand. J. Immunol. 2019, 90, e12804. [CrossRef] [PubMed]

171. Barkal, A.A.; Brewer, R.E.; Markovic, M.; Kowarsky, M.; Barkal, S.A.; Zaro, B.W.; Krishnan, V.; Hatakeyama, J.; Dorigo, O.; Barkal, L.J.; et al. CD24 signalling through macrophage Siglec-10 is a target for cancer immunotherapy. Nature 2019, 572, 392-396. [CrossRef]

172. Wong, S.-C.; Puaux, A.-L.; Chittezhath, M.; Shalova, I.; Kajiji, T.S.; Wang, X.; Abastado, J.-P.; Lam, K.-P.; Biswas, S.K. Macrophage polarization to a unique phenotype driven by B cells. Eur. J. Immunol. 2010, 40, 2296-2307. [CrossRef] [PubMed]

173. Marchesi, M.; Andersson, E.; Villabona, L.; Seliger, B.; Lundqvist, A.; Kiessling, R.; Masucci, G.V. HLA-dependent tumour development: A role for tumour associate macrophages? J. Transl. Med. 2013, 11, 247. [CrossRef] [PubMed]

174. Liu, X.; Cao, Y.; Li, R.; Gu, Y.; Chen, Y.; Qi, Y.; Lv, K.; Wang, J.; Yu, K.; Lin, C.; et al. Poor clinical outcomes of intratumoral dendritic cell-specific intercellular adhesion molecule 3-grabbing non-integrin-positive macrophages associated with immune evasion in gastric cancer. Eur. J. Cancer 2020, 128, 27-37. [CrossRef] [PubMed]

175. Li, X.; Yao, W.; Yuan, Y.; Chen, P.; Li, B.; Li, J.; Chu, R.; Song, H.; Xie, D.; Jiang, X.; et al. Targeting of tumour-infiltrating macrophages via CCL2/CCR2 signalling as a therapeutic strategy against hepatocellular carcinoma. Gut 2017, 66, 157-167. [CrossRef]

176. Park, H.-J.; Chi, G.-Y.; Choi, Y.-H.; Park, S.-H. The root bark of Morus alba L. regulates tumor-associated macrophages by blocking recruitment and M2 polarization of macrophages. Phytother. Res. 2020, 34, 3333-3344. [CrossRef]

177. Bhaskaran, N.; Ghosh, S.K.; Yu, X.; Qin, S.; Weinberg, A.; Pandiyan, P.; Ye, F. Kaposi's sarcoma-associated herpesvirus infection promotes differentiation and polarization of monocytes into tumor-associated macrophages. Cell Cycle 2017, 16, 1611-1621. [CrossRef]

178. Liao, Q.; Zeng, Z.; Guo, X.; Li, X.; Wei, F.; Zhang, W.; Li, X.; Chen, P.; Liang, F.; Xiang, B.; et al. LPLUNC1 suppresses IL-6-induced nasopharyngeal carcinoma cell proliferation via inhibiting the Stat3 activation. Oncogene 2014, 33, 2098-2109. [CrossRef]

179. Liu, M.; Zhong, Y.-B.; Shao, J.; Zhang, C.; Shi, C. Tumor-associated macrophages promote human hepatoma Huh-7 cell migration and invasion through the Gli2/IGF-II/ERK1/2 axis by secreting TGF- $\beta 1$. Cancer Biol. 2020, 21, 1041-1050. [CrossRef]

180. Liu, D.; Song, L.; Wei, J.; Courtney, A.N.; Gao, X.; Marinova, E.; Guo, L.; Heczey, A.; Asgharzadeh, S.; Kim, E.; et al. IL-15 protects NKT cells from inhibition by tumor-associated macrophages and enhances antimetastatic activity. J. Clin. Investig. 2012, 122, 2221-2233. [CrossRef] 